The Human Rights of Minority Women:

Romani Women's Rights from a Perspective on International Human Rights Law and Politics

Ravnbøl, Camilla Ida

Published in:

International Journal on Minority and Group Rights

DOI:

10.1163/157181110X12595859744123

Publication date:

2010

Document version

Publisher's PDF, also known as Version of record

Citation for published version (APA):

Ravnbøl, C. I. (2010). The Human Rights of Minority Women: Romani Women's Rights from a Perspective on International Human Rights Law and Politics. International Journal on Minority and Group Rights, 17(2010), 145. https://doi.org/10.1163/157181110X12595859744123 


\title{
The Human Rights of Minority Women: Romani Women's Rights from a Perspective on International Human Rights Law and Politics
}

\author{
Camilla Ida Ravnbøl* \\ UNICEF, Innocenti Research Centre, Florence, Italy \\ c.ravnbol@gmail.com
}

\begin{abstract}
This article explores the complexities surrounding the human rights of minority women. With analytical focus on Romani women in Europe it seeks to contribute with new insight into the grey areas of rights issues, where groups within special rights categories share different human rights concerns, by being both women and members of a minority group. Through an investigation of how contemporary human rights law and politics serve to address the concerns of Romani women, it sheds light on the challenges that the Romani women's issue presents to the international human rights framework. These challenges go beyond the Romani issue only and into larger issues of women and minorities. It raises questions as to whether the historical separation between categories of gender and race/ethnicity within the international community in practice has become a gap that isolates Romani women from the human rights attention that they claim. It is argued that in order to strengthen the validity of human rights in the lives of Romani women, as a framework that ensures their full and equal protection, special attention needs to be given to interrelated grounds and forms of discrimination. "Intersectionality" is re-introduced as a concept to frame such new approaches to the human rights of Romani women. The article is a summary version of the thesis "The Human Rights of Minority Women: Challenging International Discourses with the Case of Romani Women", for which the author was awarded the Martin Alexanderson Research Scholarship, administered by the Raoul Wallenberg Institute of Human Rights and Humanitarian Law in Lund, Sweden. This summary version brings forward the main arguments of the thesis which was an awarded EMA thesis 2006-2007 of the European University Institute in Venice.** For this reason it does not present any new findings or data after 2007 but merely summarises the main chapters of the thesis. The thesis investigated the complexities surrounding Romani women's human rights at UN and European level. Thus, national systems and the regional systems in the Americas and Africa are excluded. The empirical data comes primarily from the European region.
\end{abstract}

\section{Keywords}

Roma; Romani women; minority rights; women's rights; multiple discrimination; intersectional discrimination; universality

*) MA in Anthropology, Copenhagen University; EMA in Human Rights and Democratization, European Inter-University Centre.

**) Awarded thesis in the European Inter-University Centre's publication of the top five theses of the year: The Human Rights of Minority Women; Challenging International Discourses with the Case of Romini Women; EMA Awarded Theses, 2006/2007, published September 2008; <www .eiuc.org>. 


\section{Introduction}

Minority rights and gender equality are at the centre of contemporary human rights debates. Initiatives and resolutions are continuously developed within the United Nations (UN) and the Council of Europe (CoE) on minority inclusion and equal standards for women that also form part of the criteria for accession to the European Union (EU). ${ }^{1}$ Comprising between 8 and 12 million, the Roma are often referred to as Europe's largest ethnic minority group. ${ }^{2}$ Roma are also characterised as being amongst the most marginalised and discriminated. ${ }^{3}$ The Decade of Roma Inclusion (2005-2015) marks the international community's dedication to combat the social exclusion of Europe's Romani minorities. ${ }^{4}$ At the same time, Romani communities worldwide are increasingly organising in a fight for human rights. However, in terms of relating the doctrine of gender equality to the Romani issue, little implementation and international commitment has been seen. ${ }^{5}$ Where steps are increasingly taken to grant Roma minority status and corresponding special rights in international

1) Where international human rights law contains no definition of minorities, one recognised definition is that of the former UN Special Rapporteur of the Sub-Commission on Prevention of Discrimination and Protection of Minorities, Francesco Capotorti: "a group numerically inferior to the rest of the population of a state, in a non-dominant position, whose members - being nationals of the State - possess ethnic, religious or linguistic characteristics differing from those of the rest of the population and show, if only implicitly, a sense of solidarity, directed towards preserving their culture, traditions, religion or language", F. Capotorti, Study on the Rights of Persons belonging to Ethnic, Religious and Linguistic Minorities, UN Doc. E/CN.4/Sub.2/384/Rev.1. 1979 [1977], p. 96.

This definition does not always apply, e.g. can minorities constitute a numerical minority, such as the indigenous population in Bolivia, and today non-nationals are also included.

2) C. Fenger-Grøndahl and M. Fenger-Grøndahl, Sigøjnere: 1000 år på kanten af Europa [Gypsies: 1000 Years on the Margins of Europe] (Aarhus Universitetsforlag, 2006) p. 11. Roma/Romani (sing. and adj. e.g. Romani women) and Roma (pl. e.g. European Roma) links to the language Romanés and is a self-ascribed political umbrella terminology that gathers all the many different Romani communities, I. Klimóvá-Alexander, The Romani Voice in World Politics: The United Nations and Non-State Actors (Ashgate Publishing Limited, UK, 2005) p. 30.

3) High Commissioner on National Minorities (HCNM), by M. van der Stohl, Report on the Situation of Roma and Sinti in the OSCE Area, Organization for Security and Co-operation in Europe, 10 March 2000, p. 1.

4) The Decade is an international initiative that brings together the UN, European national governments, intergovernmental and nongovernmental organisations, as well as Romani civil society, to improve the socio-economic status and social inclusion of Roma within the European framework. See <www.romadecade.org/index.php?content=1> (consulted 15 July 2009).

5) 'The term 'gender' refers to the socially constructed roles of women and men that are ascribed to them on the basis of their sex. The word 'sex' refers to physical and biological characteristics of men and women. Gender roles reflect different social constructions of female and male identities which result from their different social positions, rather than innate female and male behaviour", C. A. Brautigam, 'International Human Rights Law: The Relevance of Gender', in W. Benedek, E. Kisaakye and G. Oberleitner G. (eds.), The Human Rights of Women: International Instruments and African Experiences (Zed Books, London, 2002) pp. 3-30. 
and national settings, the rights of Romani women have been given less attention. ${ }^{6}$ Romani women are representative of the multiple discrimination that many minority women experience in society: discrimination as a minority, as a woman, and for some women also on grounds of poverty. ${ }^{7}$ Furthermore, many Romani women not only face the challenges of discrimination in majority society but also experience gender-based discrimination internally in their own communities because of strict patriarchal traditions that place them in constrained positions.

Thus, Romani women represent a complex issue of a disadvantaged group within a minority group. How do Romani women then enter contemporary approaches on minority rights and gender equality? Many Romani women activists criticise the international community, the global Romani movement and the global women's movement for not specifically addressing Romani women's problems. Instead, their concerns are often subsumed under larger Romani minority issues, isolated from women's rights. ${ }^{8}$ This criticism raises questions to whether the traditional separation in the international field of human rights between issues of gender and minorities in practice has become a gap that can isolate groups such as minority women from human rights attention. Where the Vienna Conference in 1993 underlined the doctrine of indivisibility and interrelation of all human rights, and where mainstreaming of gender and minority perspectives into human rights programmes is increasingly an area of priority, it is rare that minority and gender issues are combined. ${ }^{9}$ On this basis, it can be argued that minority women face double disadvantages not only in social life but also within international human rights law and politics because they cross-cut categories of protection. On the other hand, it may also be possible to see Romani women's double status as a strategy to gain increased political voice and legal redress for their human rights concerns, if they manage to link to both women and minority specific frameworks.

6) European Union's Specialist Group on Roma/Gypsies, The Situation of Roma/Gypsy Women in Europe, report by N. Bitu for the 7th Meeting of the European Union's Specialist Group on Roma/ Gypsies, Strasbourg, 29-30 March 1999, p. 2, available at <www.romawomen.ro/reports_pages/ the_situation_of_roma_gypsy.htm> (consulted 15 July 2009); International Romani Women's Network (IRWN), A Place at the Policy Table: Report on the Roma Women's Forum, Budapest, Hungary, 29 June 2003, Network Women's Program, Open Society Institute, pp. 1-7, available at $<$ www.soros.org/initiatives/women/articles_publications/publications/romawomensforum_20030923/roma_womens_finalreport.pdf> (consulted 15 July 2009).

7) The interrelation of different forms of discrimination on grounds of the person's gender, race, class, etc. See discussion and definition by K. Crenshaw, 'Mapping the Margins: Intersectionality, Identity Politics and Violence Against Women of Color', 43:6 Stanford Law Review (July 1991) pp. 1241-1299.

8) IRWN, supra note 6, p. 3; A. Oprea, 'Re-envisioning Social Justice from the Ground Up: Including the Experiences of Romani Women', 1:1 Essex Human Rights Review (July 2004) p. 33.

9) Minority Rights Group International (MRG), report by F. Banda and C. Chinkin, Gender, Minorities and Indigenous Peoples, Minority Rights Group Int., 2004, p. 9. 
The thesis was inspired by the above questions regarding the barriers and possibilities minority women experience within contemporary international human rights law and politics. It aimed to add a nuance to present day human rights debates by shedding light on the grey area of rights issues, where groups within minorities act in contexts of multiple disadvantages. ${ }^{10}$ Thus, where legal and political theory mainly approaches the institutional system, focus in this thesis was on social agency within the system - namely on how social actors use and influence an international legal and political framework that positions them respectively.

The research was framed as an analysis of the barriers and possibilities Romani women experience within the existing human rights framework. It investigated how contemporary human rights law and politics serve to address Romani women's human rights concerns. On this basis it was discussed which challenges the issue of "Romani women" presents, not only to international approaches on the Roma issue, but also to larger discourses on women and minorities.

\subsection{Outline}

Law and politics are interrelated areas also within the field of human rights. Because the intention is to provide a holistic insight into the position of Romani women within human rights, both the legal and political fora where Romani women can stress and redress their human rights concerns was investigated.

First the context of Romani women in Europe is introduced, to serve as empirical background for subsequent analyses and discussions. Then an analysis is made of the barriers and possibilities that international human rights law presents to Romani women. It is discussed how the contemporary international legal framework serves to redress the human rights concerns of Romani women. The following section investigates the barriers and possibilities that international human rights politics present to Romani women. This is narrowed to focus on political initiatives and institutional developments for Roma (minorities) and women within the UN, CoE, EU and activities of the global Romani movement and the global women's movement (until the end of 2007). It is discussed how this political framework serves to address the concerns of Romani women. Last the discussions of the preceding sections are developed further into an analysis of the challenges that the issue of Romani women, and of minority women in general, presents to the international human rights project. It is discussed, how the barriers that minority women experience in raising their particular concerns within the contemporary

10) Discourses are institutionalised ways of thinking that inform social practices - social boundaries that define how to speak and act on a specific topic. See N. Fairclough, Discourse and Social Change (Polity Press, Cambridge, 1992) and M. Foucault, The Archaeology of Knowledge (Routledge, UK, 1972). 
human rights framework question the all-inclusiveness, or universal validity, of the framework. The final section gathers the discussions in a final conclusion.

\section{The Empirical Context: Romani Women in Europe}

This section focuses on important elements of Romani history and present day situations as a way to provide empirical background for understanding the contemporary situation of Romani women in Europe.

\subsection{Historical Treatment of Roma as the Remote "Other"}

Only a few original sources exist on the historical origin of the Roma, which remain a subject of large interest and dispute within academics. ${ }^{11}$ Although the past 20 years has shown a rapid increase in Romani literature written by Roma themselves, Romani history can to a large extent be seen as a history of nonRomani representation in academic and popular literature. Many of these literary works are rather informative, but many are also highly criticisable. At one extreme we find documents depicting Roma as social parasites exploiting the resources of majority society. ${ }^{12}$ At another extreme we find romanticised representations of Roma as mysterious travellers and exotic dancers who live in colourful caravans in harmony with nature. ${ }^{13}$ Common for much of this literature is that it has contributed to the production of an image of Roma as the remote "Other" - as a social category of people distinct from the majority society in identities, needs and demands. The literary image of Roma as the different "Other" reflects, and has also helped pave the way for, Romani history as also being a history of negative stereotyping and social exclusion.

Records of outlawing, containment and extermination of Roma can already be found in early European history. Enslavement of Roma occurred in many states and was last abolished in 1864 in Romania. ${ }^{14}$ In the 20 th century negative

\footnotetext{
11) Today, consensus exists within academics that India is the country of origin (although the dates and waves of migration remain disputed between year 500 and 1000 A.D.), and that the language Romanés has roots in Sanskrit. Klimóvá-Alexander, supra note 2, p. 13; Fenger-Grøndal and Fenger-Grøndal, supra note 2, p. 22.

12) See discussion on Peytster 1882 and Anon 1856 in I. Hancock, We are the Romani People (University of Hertfordshire Press, 2002) p. 33, and quotations from documents from Bologna 1422, Germany 1496, Netherlands 1525 and Sweden 1637 in Minority Rights Group International (MRG), Report by J. P. Liegeois and N. Gheorghe, Roma/Gypsies: A European Minority, 1995, pp. 19-20, available at <www.minorityrights.org/> (consulted 15 July 2009).

13) E.g. Victor Hugo's depiction of Esmeralda in the Hunchback of Notre Dame (1831) and Isabella Fonseca's Bury me Standing (1996).

14) HCNM, supra note 3, p. 19; Klimóvá-Alexander, supra note 2, p. 14; Hancock, supra note 12, p. 25.
} 
stereotypes of Roma continued to be strong in many European states that had harsh anti-Romani laws and policies. One example is policies on coercive sterilisation of Romani women that were practiced in for example Sweden up until 1975. ${ }^{15}$ Other laws in for example England prohibited Romani settlement. The most extensive attempt of elimination of the Romani population was seen during the Holocaust in World War II where an estimated quarter to a half million Roma were exterminated in concentration camps due to their ethnic origin. ${ }^{16}$ Significant attempts of eradication of traditional Romani culture were seen during communist rule in Central and Eastern Europe and South-Eastern Europe (hereafter CEE and SEE). During this period extensive assimilation programmes prohibited the use of the language Romanés, enforced settlement, etc. ${ }^{17}$ Post1989 transformations in CEE and SEE have shown deterioration in the situation of Roma in some areas. The reasons for this are highly disputed amongst scholars. The rapid transition to a market economy with the growing differences between rich and poor, the increased focus on nation building and the remaining impact of discriminatory communist policies are regarded as some important factors behind the contemporary problems of marginalisation and discrimination of Roma in the regions. ${ }^{18}$

\subsection{Insight into Contemporary Situations of the European Roma}

The contemporary situation of Roma in Europe must be understood in the light of their history. There is a high degree of mistrust in state institutions. Many Roma in Europe are marginalised in society. They live in poverty, dependent on social welfare, with poor health conditions, and little possibilities of education, employment and political participation. ${ }^{19}$ Social and institutional discrimination of Roma remains a significant problem in many European states and is often of a structural character. ${ }^{20}$ Roma experience exclusion from health care,

15) Equality Ombudsman (DO) report, Discrimination against Roma in Sweden, 2004, p. 8; FengerGrøndahl and Fenger-Grøndahl, supra note 2, p. 324.

16) Klimóvá-Alexander, supra note 2, p. 14, HCNM, supra note 3, p. 21; Hancock, supra note 12, pp. 34-53.

17) HCNM, supra note 3, pp. 21-22.

18) For further discussion, see e.g. M. Stewart, Time of the Gypsies (Westview Press, UK, 1997) and Klimóvá-Alexander, supra note 2.

19) United Nations Development Programme (UNDP), The Roma in Central and Eastern Europe: Avoiding the Dependency Trap, 2002, pp. 1-5 and 31-68, available at <europeandcis.undp.org/? menu=p_cms/show\&content_id=62BBCD48-F203-1EE9-BC5BD7359460A968> (consulted 15 July 2009).

20) "Whereas the 12-15 million Roma living in Europe, 7-9 million of whom live in the European Union, suffer racial discrimination and in many cases are subject to severe structural discrimination, poverty and social exclusion", European Monitoring Centre on Racism and Xenophobia (EUMC) see now European Union Agency for Fundamental Rights (FRA), Roma and Travellers in Public 
education, housing, employment, social services, political life and other important areas of social life. Racial stereotypes and prejudice are common, exemplified by cases where Romani children have been placed in school-classes for mentally disabled children although showing no signs of mental disabilities. ${ }^{21}$ Ethnic discrimination in the justice system is also a significant problem in many states where anti-Romani biases in police forces and other organs of the justice system cause ineffective remedy and lack of procedural guarantees for Roma. ${ }^{22}$ Racially motivated violence on person and property perpetrated by police officers and non-state actors is likewise a concern in many countries. ${ }^{23}$ Approaching Romani history as a history of social exclusion thus reveals a range of significant human rights concerns.

Romani history is also a history of plurality and internal resistance. Scattered across the region with no nation-state to call their own, the between 8 to 12 million Roma in Europe have inevitably come to share a history of diversity. They inhabit significantly different contexts, which mean that traditions, norms, dialects and self-appellations often vary between the groups. ${ }^{24}$ Despite this diversity, Roma across the world emphasise how they share fundamental linguistic, cultural and historical commonalities that tie them together as, what is today by many Roma argued, a non-territorial Romani nation. ${ }^{25}$ "Roma/Romani" thereby becomes the political umbrella term to represent Roma as a united people that embrace its internal heterogeneity. The international human rights community does not recognise the self-identification as a "people" or nation but regard Roma as a minority group that requires special minority protection

Education: An Overview of the Situation in the EU Member States, Vienna, 2006, p. 129, available at <fra.europa.eu/fraWebsite/material/pub/ROMA/EUMC_2006_00350001_EN_REV.pdf> (consulted 15 July 2009); Fenger-Grøndahl and Fenger-Grøndahl, supra note 2; HCNM, supra note 3 . Structural discrimination is systematic ways in which a given social structure or social institution discriminates a particular group of people through laws/policies and behaviour of persons who implement the laws/policies and control these institutions. These are either directly discriminating or neutral in intent but with a differential and/or harmful effect on the given group in question. See <gradschool.gallaudet.edu/clc2002/Readings/PINCUS.PDF> (consulted 5 July 2007).

21) EUMC, ibid., pp. 8 and 46; European Parliament, Report on the Situation of Roma Women in the European Union (2005/2164(INI)), Committee on Women's Rights and Gender Equality, Rapporteur Lívía Járóka, Final A6-0148/2006, 27 April 2006, p. 5, available at <www.soros.org/ initiatives/women/news/landmark_20060602/EP_resolution.pdf> (consulted 15 July 2009); UNDP, supra note 19, p. 55.

22) EUMC, ibid., p. 130.

23) EUMC, ibid., p. 19; HCNM, supra note 3, pp. 35-37; UNDP, supra note 19, p. 71; and ERRC $<$ www.errc.org/>.

24) E.g. some use self-appellations as Kale, Sinti, Romanichal instead of "Roma" that is most common in the Central and Eastern European region. Klimóvá-Alexander, supra note 2, p. 30.

25) Klimóvá-Alexander, supra note 2, pp. 19-22; N. Gheorghe, 'The Social Construction of Romani Identity', in T. Acton (ed.), Gypsy Politics and Traveller Identity (University of Hertfordshire Press, 1997) pp. 153-172, at p. 161; Hancock, supra note 12. 
measures. ${ }^{26}$ This growing political consciousness is important for understanding the contemporary political situation of Roma in Europe. The global Romani movement took significant form from the beginning of the 1990s, and the number of Romani social and political organisations is increasing. ${ }^{27}$

\subsection{The Missing Voices of Women in Romani History}

Romani women have historically received scarce attention within academics and within the international field of human rights. In the growing body of literature on Romani culture and documentation on violations of the human rights of Roma, the rights of women and the different situations for men and women have been less documented. ${ }^{28}$ This is not a problem particular to this group but a general problem of female under-representation in literature/documentation that has been criticised by many scholars, such as by the British anthropologist Michael Stewart. Stewart criticises his own negligence of women during his fieldwork in a Romani settlement in Hungary:

There are however, and perhaps inevitably, serious gaps in my knowledge. I know much less about how women talked with each other and behaved when there were no men present than I would like. I am particularly aware that I give no sense of a critical, alternative or even substantive discourse, however fragmentary, among women. ${ }^{29}$

It has been argued by the American anthropologist Edwin Ardner that one reason for this neglect can be found in a general tendency within academics to place men in the public sphere, and thus regard men as primary spokesmen of local culture. ${ }^{30}$ Ethnographies on women, Stewart's ethnography included, more often focus on women in the private sphere as mothers, spouses and managers of the household. While these divisions are frequently found in many communities, it is highly misleading to operate uncritically with private/public distinctions. This withdraws women from political and cultural production and presents narrowed insight into important aspects of community life.

26) It has been suggested that Roma constitute a tribal people in Europe according to Article 1(1) and (2) ILO Convention 169. However the UN does not recognise this term (G. Alfredsson, 'Minorities, Indigenous and Tribal Peoples, and Peoples: Definitions of Terms as a Matter of International Law', in N. Ghanea and A. Xanthaki (eds.), Minorities, Peoples and Self-determination (Koninklijke Brill NV, Netherlands, 2005) pp. 163-172, at p. 169). p. 169).

27) Gheorghe, supra note 25, p. 160; EUMC, supra note 20, p. 19.

28) Asylum Aid, Romani Women from Central and Eastern Europe: A "Fourth World", or Experience of Multiple Discrimination, Asylum Aid Refugee Women's Resource Project, 2002, p. 17, available at $<$ www.asylumaid.org.uk> (consulted 15 July 2009).

29) Stewart, supra note 18, p. 12.

30) E. Ardner, 'Belief and the Problem of Women', in T. H. Eriksen (ed.), Socialantropologiske Grunntekster (Gyldendal Norsk Forlag, Oslo, 2001) pp. 197-214, at pp. 198-200. 


\subsection{Insight into Contemporary Issues for Romani Women}

The situation of under-representation of Romani women is, however, slowly changing, and recent literature also written by Romani women themselves reveals how they are not only tied to the private sphere. Historically, women have played a central role as mediators and negotiators between the private family and the non-Romani public sphere, e.g. in communication with their children's schools and social services. ${ }^{31}$ Furthermore, a number of Romani women are active in national and international political spheres where they raise concerns on the particular situation of Romani women.

The concerns that many Romani women activists raise in regards to the situation of Romani women in majority society go beyond the concerns that they share with the Romani minority group as a whole and into specific minority women's problems. Reports show that many experience multiple discrimination in society, as being women, minorities and in some cases for being poor (low class status) or on grounds of age (Romani girls or elderly women). ${ }^{32}$ Many Romani women activists emphasise that the consequence of this multiple discrimination is that the women are excluded from many areas of social and institutional life. They face disadvantages in education and few finish primary education in comparison to majority society children and also in comparison to Romani men. ${ }^{33}$ A comprehensive investigation of the health situation of Romani women in Europe shows that many experience anti-Romani attitudes in state health care sectors where they are refused assistance in hospitals even in urgent matters such as child delivery. ${ }^{34}$ When admitted into hospitals they experience verbal abuse and degrading treatments in the form of for example sexual and racial namecalling or segregation in special Romani maternity wards. The report also highlights how the life expectancy for Romani women in Europe is significantly lower than that of majority society and male Roma, which is related to their difficult

31) European Roma Rights Centre (ERRC) Roundtable Meeting, 'Roundtable: Romani activists on women's rights' (includes article by S. Xhemajli, 'Everything we don't want to hear', pp. 28-30 and responses by participants in the Roundtable pp. 30-37), 1 Roma Rights Quarterly Journal of the European Roma Rights Centre (2000) response by Ivanov at p. 35.

32) Berliner Institut für Vergleichende Sozialforschung (BVIS), Economic Aspects of the Condition of Roma Women, IP/CFEMM/2005-09, Report prepared for the European Parliament DG of Internal Policies, Citizen's Rights and Constitutional Affairs (RMD 3J 24/26), April 2006, available at <www.pedz.uni-mannheim.de/daten/edz-ma/ep/06/pe365970-en.pdf> (consulted 15 July 2009); IRWN, supra note 6, pp. 2-7; European Parliament, supra note 21, p. 4; EUMC, supra note 20, p. 129.

33) IRWN, supra note 6, p. 13.

34) European Monitoring Centre on Racism and Xenophobia (EUMC) - see now European Union Agency for Fundamental Rights (FRA), Breaking the Barriers: Romani women's access to public health care, Office for Official Publications of the European Communities, Luxembourg, 2003, pp. 39-42, available at <fra.europa.eu/fraWebsite/products/publications_reports/pub_tr_romaniwomen_ healthcare_3_en.htm> (consulted 15 July 2009). 
access to health care. ${ }^{35}$ In some countries it is also a result of poor housing conditions with unsatisfactory sanitary conditions. Inadequate housing conditions, or in some countries forced evictions of Romani families, is a crucial problem for mothers with children. Reports indicate that the combination of racial and gender-based violence or exploitation is a significant problem for Romani women in Europe, in particular in the CEE and SEE countries. ${ }^{36}$ This can take the form of verbal or physical abuse for example when wearing their traditional dresses in restaurants, shops or other public spaces. ${ }^{37}$ Rape with racial dimensions is another form, most commonly perpetrated by civilians but some cases also involved police agents. ${ }^{38}$ Romani women have a high representation amongst victims of trafficking in Europe. ${ }^{39}$

Coercive sterilisation of Romani women in hospitals in the Czech Republic and Slovakia is still reported, where omission and insufficient national laws within the area of criminal law and sterilisation has many times left these cases in impunity, although highly criticised by the international community. ${ }^{40}$ Prejudice and discrimination in the justice system is also a significant problem for Romani women in some areas, where crimes committed against them, such as rape, racial attacks and domestic violence, are left un-investigated and un-prosecuted as "gypsy" matters and/or private matters. ${ }^{41}$ The activists also raise concerns on the significant disadvantages Romani women face in economic life (employment) and in political participation in state and local administrations and in national parliaments in many countries in Europe. Together, the empirical examples illustrate how Romani women experience various forms of human rights violations on the basis of their gender and their ethnic origin in combination. Chapters three and four on Romani women and international human rights law pick up on this discussion.

Some Romani activists also turn their critical eye to the situation of women internally in Romani communities and families:

35) Ibid., pp. 39-48.

36) European Parliament, supra note 21, p. 6, Asylum Aid, supra note 28; Center for Reproductive Rights in New York and Centre for Civil and Human Rights of Poradna, Body and Soul: Forced Sterilization and Other Assaults on Roma Reproductive Freedom in Slovakia, 2003, available at $<$ reproductiverights.org/en/document/body-and-soul-forced-sterilization-and-other-assaults-onroma-reproductive-freedom> (consulted 15 July 2009).

37) Equality Ombudsman, supra note 15, p. 15.

38) Asylum Aid, supra note 28, p. 48.

39) European Parliament, supra note 21, p. 5 and <www.osce.org/odihr/18158.html> (consulted 18 May 2007).

40) Center for Reproductive Rights in New York and Centre for Civil and Human Rights of Poradna, supra note 36. For a more detailed discussion on the legal aspects of coercive sterilization of Romani women in the Czech Republic, see M. Kopalová, 'Coercive Sterilization in Czech Republic: Civil and Criminal Law Aspects', 4 Roma Rights Quarterly Journal of the European Roma Rights Centre (2006) pp. 27-31, at pp. 27-30.

41) Asylum Aid, supra note 28, p. 54; Kopalová, ibid., p. 30. 
For the greater part of the Romani community, the honour of the family is the most important thing, and the chastity and the purity of women is central to that honour. Public opinion is a very important part of the life of the Roma. To maintain a good public image, Romani parents exercise strict control over the girls of the family from an early age. ${ }^{42}$

Women activists highlight problems in patriarchal communities and families of differential treatment between girls and boys, where the girl/woman is bound by traditions and responsibilities that prevent her from finishing her education and/or engaging in employment. They criticise traditions of early and arranged marriages and virginity cults that are practiced in some communities and families for violating the free choice and sexual and reproductive rights of the girl child. ${ }^{43}$ The activists are also critical towards traditions of silencing (tabooing) of sexuality, homosexuality, trafficking, prostitution and AIDS. ${ }^{44}$ These traditions prevent girls from receiving sexual education and prevention information concerning rape and trafficking. The activists are particularly concerned with the high percentages of domestic violence in Romani families that is often also treated within a culture of silence, thereby limiting the women's possibilities for reacting against the domestic abuse. ${ }^{45}$ Thus, Romani women activists are critical towards various particular practices and traditions within some Romani families and communities, which they argue cause gender-based discrimination and violate women's individual human rights. They argue that as a consequence hereof many women feel in conflict with Romani culture.

In their advocacy, the activists call upon the responsibility of several actors to recognise and redress Romani women's concerns: namely the Romani family and local community, majority society, national governments and the international community. While on the one hand operating as part of the larger Romani movement, the women on the other hand also criticise the Romani movement, the global women's movement and the international community for not giving sufficient attention to Romani women:

The work done by Romani women aimed at combating triple marginalization is not considered "Romani politics". Nor is it given due respect as gender politics, since it deals with Romnia who are considered Gypsies not women ... ${ }^{46}$

42) ERRC Roundtable, supra note 31, response by Ivanov at p. 35.

43) ERRC Roundtable, supra note 31, article by Xhemajli at pp. 28-30; IRWN, supra note 6, p. 3.

44) IRWN, supra note 6, and additional information on homepage <www.romawomensinitiative .org>.

45) European Union's Specialist Group on Roma/Gypsies, supra note 6, p. 7; C. Cahn, 'Nexus: domestic violence, Romani courts and recognition', 1 Roma Rights Quarterly Journal of the European Roma Rights Centre (2000) pp. 42-46, at p. 42; IRWN, supra note 6, p. 5.

46) "Romnia" is used as a feminine form of Roma in Oprea, supra note 8, p. 33. 
The empirical chapter serves as background for the coming investigation of the barriers and possibilities Romani women face when turning to international human rights law and politics to stress and redress their human rights concerns. On this basis the challenges that the issue of minority women present to contemporary human rights approaches is discussed. The first area of analysis is Romani women and international human rights law.

\section{Romani Women and International Human Rights Law}

Romani women can use litigation as a strategy to redress the human rights violations they experience. However, minority women's rights have traditionally received scarce attention within international law. The reasons for this are several, one being that women's rights and minority rights, although being of continuous concern throughout the history of international law, have only recently developed as special legal fields. ${ }^{47}$ Thus, approaching the legal aspects of the Romani women's issue opens for questions on how the women can use the existing law to claim justiciability and international recognition. This section presents an analysis of the barriers and possibilities international human rights law presents to Romani women. It identifies legal rights and discusses jurisprudence relevant for Romani women including future possibilities for litigation. The intention is not to provide a full legal overview but to draw attention to important aspects. The areas covered are general human rights law, and human rights law of women and minorities elaborated on UN and European level. Because Romani issues have most frequently been approached as minority issues, this body of law is presented first in the analysis.

\subsection{The Human Rights of Minorities}

A reading of the substantive content of international human rights law relevant for minorities, identifies the overall objectives in regards to minorities as two-fold, namely non-discrimination and special rights/measures. ${ }^{48}$ Non-discrimination is

47) S. Spiliopoulou Åkermark, Human Rights of Minority Women: A Manual of International Law (Åland Islands Peace Institute in co-operation with Åbo Akademi University Institute for Human Rights, 2000) p. 11.

48) Article 27 in the International Covenant on Civil and Political Rights (ICCPR, 1966) was for a long time the only provision in international human rights law that explicitly concerned minorities. History, however, has shown general human rights law to be inadequate in presenting solutions to the most important concerns of minorities. Consequently, specific minority rights have been elaborated as complementary to general human rights law. At the international level these rights are laid out in the United Nations Declaration on the Rights of Persons Belonging to National, Ethnic, Religious and Linguistic Minorities (UNDM, 1992). This Declaration is often referred to as an authoritative interpretation of Article 27 ICCPR and was the first international document to 
generally established in international human rights law. ${ }^{49}$ The main features of discrimination that concern minorities are distinction, exclusions, restrictions or preferences on unwarranted grounds of race, ethnic or national origin, language and religion. The essence of non-discrimination follows the principle of equality of treatment. ${ }^{50}$ This includes the rights of minorities to equality before the law and before the courts, equal access to public services, work and education, etc. It also includes fundamental freedoms. Freedom of expression, freedom of association and assembly, the right to information in preferred language, the right to hold religious beliefs of own choice and freedom of movement are all crucial freedoms for the protection and promotion of identities and cultures of minorities. $^{51}$

The most comprehensive approach to racial/ethnic discrimination is presented in the International Convention on the Elimination of All Forms of Racial Discrimination (CERD 1966). Both direct and indirect discrimination are comprehensively targeted and a clear link is drawn to non-discrimination as required to ensure equality. Article 5 provides a list of specified civil and political rights and economic, social and cultural rights where the state must ensure nondiscrimination and equality for racial/ethnic groups. This includes the express right of access to public places and services such as in public transport, parks and restaurants (Article 5(f)). Together with the negative obligation of nondiscrimination, CERD also establishes positive obligations to fulfil and protect. This includes punishment of those accountable for racial incitement, protection and remedies against racial discrimination, and immediate and effective measures for the prevention of discrimination. ${ }^{52}$ It furthermore permits affirmative action

comprehensively address the rights of persons belonging to minorities. At European level minority rights are defined in the European Framework Convention for the Protection of National Minorities (FCNM, 1995) and the European Charter for Regional or Minority Languages (1992). Also the OSCE High Commissioner on National Minorities (HCNM) has played a large role in the development of international minority standards in recommendations on the educational, linguistic and political rights of minorities. These are based on the OSCE Copenhagen Meeting Document (1990) that has also inspired the work of the UN and Council of Europe on minority issues. Notably, the Copenhagen Document refers specifically to the discrimination of Roma in Article 40. This development of a special legal field of minority rights signifies that persons belonging to minorities are entitled to human rights for all as well as to specific rights.

49) UDHR, Article 2; ICCPR, Article 2(1) and Article 26; ICESCR, Article 2(2); ECHR, Article 14.

50) A. Eide, 'The Non-inclusion of Minority Rights: Resolution 217C (III)', in G. Alfredsson and A. Eide (eds.), The Universal Declaration of Human Rights: A Common Standard of Achievement (Kluwer Law Intenational and Martinus Nijhoff Publishers, The Hague, 1999) pp. 701-723, at p. 714 .

51) Freedom of association (UDHR, Article 20; ICCPR, Article 22; ECHR, Article 11). Freedom of expression and information (UDHR, Article 18; ICCPR, Article 18; ECHR, Article 10). Freedom of assembly (UDHR, Article 20; ICCPR, Article 21; ECHR, Article 11).

52) M. Nowak, Introduction to the International Human Rights Regime, The Raoul Wallenberg Institute Human Rights Library, Volume 14 (Martinus Nijhoff Publishers, Leiden, 2003) p. 85. 
in order to ensure advancement and equal enjoyment of human rights and fundamental freedoms of certain racial and ethnic groups. ${ }^{53}$ The rights established in CERD are therefore important for the effective protection and advancement of ethnic/racial minorities, although not being minority particular rights. Important to include in this connection is that the CERD Committee has taken progressive steps for the non-discrimination of Roma. They are referred to in several state reviews, and General Comment no. 27 specifically concerns Roma. ${ }^{54}$ This is the first time that the treaty body has dealt specifically with a subject group, and the document also includes particular references to Romani women. Notably, General Comment no. 27 and the recent state reviews illustrate how there is growing attention within the Committee towards multiple discrimination of Romani women and of minority women in general. ${ }^{55}$ Although no CERD jurisprudence yet exists on the issue, the recent developments are highly important for Romani women and will be discussed in depth in this article.

Special rights/measures are the second area of important rights for minorities that can be identified within international human rights law. ${ }^{56} \mathrm{Few}$ special rights can be interpreted out of general human rights law. Such are particularly elaborated in the minority specific instruments where negative obligations of noninterference are supported by positive obligations for the state to ensure the effective realisation of human rights for minorities through special measures. ${ }^{57}$ Special rights/measures include amongst other things: the right of a minority to exist as a group in addition to the right to life of the individual; protection and promotion of minority identity in the fields of education, culture, language and religion; the right to traditional economic activities and to rely on special resources for existence; the right to use the minority group's language in private and for certain official purposes; guarantees in the administration of justice; and the right to communicate with kin in different parts of the world and within the State. ${ }^{58}$

\footnotetext{
53) CERD, Article 1(4).
}

54) General Comment no. 27: Discrimination against Roma: 16/08/2000, reference to Romani women in Articles 6, 7, 34 and 46.

55) E.g. CERD on sterilisation of Romani women in Slovakia: Concluding Observations 10/12/2004, UN. Doc CERD/C/65/CO/7. See also CERD on multiple discrimination against Romani women in Ireland (Travellers): Concluding Observations 14/04/2005, CERD C/IRL/ $\mathrm{CO} / 2$.

56) UDHR, Article 26 and ICESCR, Article 13; Convention on the Punishment and Prevention of the Crime of Genocide (1948); UNESCO's Convention against Discrimination in Education (1962); CERD (1966); United Nations Convention on the Rights of the Child (CRC, 1989); UNESCO's Declaration on Race and Racial Prejudice (1978); and the Declaration on the Elimination of All Forms of Intolerance and of Discrimination Based on Religion or Belief (1981).

57) UNDM, FCNM and the European Charter for Regional or Minority Languages.

58) G. Alfredsson, Minority Rights and Democracy, submitted to the Third Strasbourg Conference on Parliamentary Democracy, Strasbourg, 16-18 September 1991, Secretariat: Council of Europe SXB.CONF (III) 8, 1991, pp. 4-5. 
Political participation of minorities can be guaranteed for example through reserved seats in the legislature or other political organs; appointment of officials chosen by the group to specific post or quotas; consultation about matters affecting them; and constitutional or legislative recognition of minority laws. ${ }^{59}$ Thus, special rights and measures for minorities include economic, social and cultural rights as well as civil and political rights. Particular emphasis is placed on the fields of education, language, culture and religion, which are regarded as crucial for the preservation and promotion of the identities and cultures of minorities. Examples are mother-tongue instruction, multi-cultural and intercultural education and the rights of minorities to manage their own institutions. ${ }^{60}$

Special measures for minorities in some cases necessarily involve a collective element in their practical realisation, such as political self-government rights and the right to manage own institutions, etc. Most human rights law focusses on the rights of the individual. This is also the case with the majority of the minority specific documents that recognise collective rights as individual rights to be enjoyed in community with other members of the group. However, in some instances direct group rights are established, notably in CERD which also allows groups-communications under the complaint mechanism. Neither the Human Rights Committee (HRC) nor the European Court of Human Rights (ECtHR) have jurisdiction to decide on group complaints.

Most minority specific rights have the limitation that minorities in the exercise of their rights and fundamental freedoms must respect the rights of others. ${ }^{61}$ According to Thornberry, this limitation can be interpreted as covering instances where certain traditional practices, customs and rules disadvantage or even violate the rights of persons within the minority group. Thornberry refers specifically to practices harmful to women. ${ }^{62}$ However, the limitation provisions in the minority instruments make no reference to women. In fact, besides Articles 11(1) and 14 in the European Framework Convention for the Protection of National Minorities (FCNM 1995), which concern minority women's language rights, minority rights are gender-neutral and no minority rights include specific women's concerns. Furthermore, little and only indirect reference to women exists in jurisprudence on minorities. Approximately 30 minority rights cases have been brought before the HRC under Article 27 of the International Covenant on Civil and Political Rights (ICCPR). ${ }^{63}$ Only two cases concerned minority women, namely Lovelace

59) HCNM, Lund Recommendations on the Effective Participation of National Minorities in Public Life (1999).

60) FCNM, Article 12, 13 and 14.

61) UNDM, Article 8(2); FCNM, Article 20. See also ICCPR, Article 5(8).

62) P. Thornberry in Spiliopoulou Åkermark, supra note 47, pp. 53-54.

63) <minority-rights.org/docs.php\#cases>. 
v. Canada ${ }^{64}$ and Lubicon Lake Band v. Canada. ${ }^{65}$ In neither of the cases did the HRC address the gender-aspects.

Neglect of gender-aspects in minority cases is also seen in Romani jurisprudence under the HRC, CERD Committee and ECtHR. The most frequent strategy in Romani litigation under international and European bodies has been to submit communications under the European Convention on Human Rights (ECHR) and CERD. ${ }^{66}$ However, in this litigation minority concerns are generally put forward and gender concerns are excluded or made secondary issues, which in some instances does not do full justice to the case. This was evident in the case Buckley v. United Kingdom, where a Romani woman was denied permission to live in a caravan on a land-site she herself owned, with the argument that other areas had been selected specifically for Roma caravans. ${ }^{67}$ The European Commission treated the case under the right to protection of family life and found no violation. ${ }^{68}$ The Commission's decision has received much criticism because the UK Caravan Sites Act 1968 can be regarded as specifically discriminatory against Roma, and thus the case could have been approached as a case of minority discrimination. ${ }^{69}$ Furthermore, it has been highly criticised that substantive gender-implications of the case were never taken into consideration. The Roma caravan site lacked sufficient sanitation and water facilities and was thus a highly inadequate housing area for Ms. Buckley, being a single mother with three children. ${ }^{70}$ This case is a representative example of a broad range of Romani cases that could have had a significantly different outcome if attention had been given to women's human rights also in conjunction with minority rights (thus with a more effective use of ECHR Article 14). This form of litigation would have obliged the state to establish specific measures for the protection of the Roma minority and in particular for Romani women.

Other examples are cases concerning ill treatment of Romani women at hospitals and cases of refused assistance when calling for ambulances in matters of delivery. ${ }^{71}$ These cases are most often approached as cases of ethnic discrimination and gender-aspects are downplayed; thereby not grasping the multiple violations this is of the rights of the women in question.

\footnotetext{
64) Sandra Lovelace v. Canada, Communication No. 24/1977, UN Doc. A/36/40(1981).

65) Lubicon Lake Band v. Canada, Communication No. 167/1984, UN Doc. A/45/40 (1990).

66) European Roma Rights Centre, <www.errc.org/Databases_index.php> (consulted 7 June 2007).

67) Buckley v. UK, Application No. 20348/92, (25/9/1996).

68) ECHR, Article 8.

69) ECHR, Article 14. This case exemplifies the limitations in the use of Article 14 in ECtHR jurisprudence. Protocol 12 to the ECHR has been elaborated in order to ensure more efficient implementation of Article 14.

70) This critique was raised by an official from the International Romani Union and by a member of the chamber which dealt with the case, see Spiliopoulou Åkermark, supra note 47, p. 69.

71) ERRC report, Ambulance not on the way: the disgrace of health care for Roma in Europe, pp. 47-59.
} 
Summing up, the combination of lacking references to women in minority relevant and minority specific human rights law with the disregard of genderaspects in jurisprudence on minorities opens for questions as to whether minority women's human rights concerns can be adequately addressed within the international legal framework of anti-racism/minority rights. The empirical section illustrated how Romani women may experience significant human rights violations also connected with their gender and thus of a different nature than their male community members. Considering this negligence of gender-aspects within the minority rights framework, it is necessary to investigate if the women's human rights category can be considered more adequate to address Romani women's human rights concerns.

\subsection{Minority Rights as a Strategy to Redress "External" Discrimination}

The minority rights framework challenges by presenting general solutions to minority issues that have often been regarded as controversial and national specific by the international community. It makes ethnicity, culture, religion and language matters of public concern. The various instruments, and in particular the comprehensive list of rights in CERD, provide minorities with tools to redress the discrimination they experience in society. They can call on special measures to ensure their full advancement and enjoyment of rights on an equal footing with the majority. Thus, Romani women can use anti-racial and minority-specific provisions as legal tools to redress the ethnic discrimination they experience either individually or together with other members of the Roma community. In other words, anti-racist and minority specific human rights law can be regarded as crucial tools to target external discrimination, namely discrimination against them as ethnic and/or national minorities in society. ${ }^{72}$

In some cases, minority rights can indirectly benefit minority women's advancement also as women, e.g. through educational measures and quotas for minority representation in economic and political life. It is relevant to consider using antiracist/minority rights further for the advancement of Romani women. For example can the right to access to public spaces and services for racial/ethnic groups in CERD, Article 5(f), be used against the discrimination Romani women experience in restaurants and other public areas when wearing their traditional dress. ${ }^{73}$ The prohibition of interference with the personal integrity of minorities under the Framework Convention can be used against the coercive sterilisation of

\footnotetext{
72) The adoption of the terminology internal and external discrimination is inspired by Kymlicka's terminology on group rights for external or internal restriction. See W. Kymlicka, Multicultural Citizenship: A Liberal Theory of Minority Rights (Oxford University Press, 1995) p. 35.

73) CERD, Article 5 (f).
} 
Romani women (FCNM Article 16). ${ }^{74}$ These avenues are still untested waters for the litigation of minority women's cases. However, CERD's comprehensive catalogue of non-discrimination rights together with the emerging collection of Romani jurisprudence plus the General Comment 27 on the Roma indicate a growing attention to the Romani issue within this treaty body. Seeing this development together with the recent awareness on the multiple discrimination of minority women, also particularly of Romani women, in General Comment no. 27 and in recent state reviews indicate that CERD is a legal avenue that could be explored further for the litigation of Romani women's cases.

Nevertheless, CERD and the minority rights framework have significant limitations in regards to addressing minority women's concerns. The non-discrimination approach in CERD and in minority rights does not distinguish between subjects within the racial/minority group, but focuses on the group as a whole. The language is gender-neutral and furthermore explicitly refers to racial/ethnic discrimination against the group in public life. ${ }^{75}$ Thus, other forms of discrimination that only concern some members of the group (as gender-based discrimination) and have an internal character (discrimination not against the group but within the family and/or community itself) are rarely approached within this legal discourse. The Lovelace v. Canada case before the HRC is an example. The case concerned an Indian woman, who was subject of gender-discriminatory laws in the Canadian Indian Act. Sandra Lovelace was not allowed to return to her ancestral land because she lost status as member of the Indian community after marrying and subsequently divorcing a non-Indian man. ${ }^{76}$ This law did not have similar consequences for male members of the Indian community who married non-Indian women. The HRC treated the case under Article 27 (minority rights) and did not engage in the "internal" aspects of the case, namely in the discussion on genderbased discrimination within the Indian community. Although minorities are bound to respect the rights of others when exercising their rights under international human rights law, the limitation provisions do not specifically refer to women and are rarely used to confront this form of inequality between men and women within minority communities. ${ }^{77}$

It can also be argued that the anti-racist/minority rights approach can lead to a further disempowerment of women. It embraces a third dimension of community rights, towards which the human rights community has traditionally been

\footnotetext{
74) FCNM, Article 16 and Spiliopoulou Åkermark, supra note 47, p. 16.

75) Article 1 of CERD explicitly defines discrimination within public life.

76) Sandra Lovelace v. Canada, Communication No. 24/1977, UN Doc. A/36/40(1981), and Spiliopoulou Åkermark, supra note 47, pp. 50-52.

77) Minority limitations are mostly discussed in relation to the harmful practices of female genital mutilation and infanticide, prenatal sex selection and dowry-related violence. Spiliopoulou Åkermark, supra note 47, p. 54.
} 
reluctant out of fear that this will cause conflicts between and within minority and indigenous groups. A dominant view within the human rights field has been that group rights may violate the individual rights of the members within the group (such as women) and thus undermine the human rights project as such. ${ }^{78}$ This argument particularly targets normative pluralism and is also relevant for many Romani women and minority women in general. The empirical chapter showed how family honour within some families/communities is closely tied to patriarchal traditions that limit women's freedoms to engage in education, employment, etc. Traditions of early marriage, virginity cults and silencing of domestic violence and sexuality interfere with her individual freedoms, personal integrity, sexual and reproductive rights and information rights. In some cases normative pluralism exists not only on community level but also on state level where personal status laws are common legal practice (e.g. in countries practicing Sharia law). Thus, when normative rules dominate above state law, or are neglected by the state, and when these norms subordinate women, there is indeed a risk of violating women's individual rights.

In this regard, it is argued that the problem lies not in an inherent dichotomy between individual and group rights. ${ }^{79}$ To the contrary, jurisprudence on minorities illustrates how both types of rights are important for many minorities. This is equally important for many Romani women who fight both for their individual rights and for their right in association with other members of the group to protect and develop Romani culture and identity through for example management of own institutions. Thus, group rights and the group complaint mechanism under CERD and the Convention on the Elimination of All Forms of Discrimination Against Women (CEDAW) are crucial for Romani women's equal enjoyment of human rights. The problem lies more in the intentions behind the minority group's claims for group rights, if they are meant for internal or external restriction. Group rights meant for internal restriction have the potential of violating the rights of the individual members, as was the case in the very traditional Romani communities that maintain family integrity above, and sometimes at the expense of, the rights and freedoms of individual community members. ${ }^{80}$ External restrictions may, however, be fundamental for the preservation and development of the cultures and identities of minorities. ${ }^{81}$ This is also the case for Roma, who throughout history have been subjects of systematic segregation or assimilation

\footnotetext{
78) Alfredsson, supra note 26, p. 165; C. Johnsson, Nation States and Minority Rights A Constitutional Law Analysis, University of Uppsala, Uppsala, Sweden, Faculty of Law, PhD thesis, 2002, pp. 33-40.

79) Kymlicka, supra note 72, p. 35; Johnsson, ibid., pp. 36-40.

80) Some communities maintain the use of the traditional Romani internal dispute settlement institution (Criss). This is a tribunal-based court system adjudicated by elders. Cahn, supra note 45, p. 42.

${ }^{81)}$ Johnsson, supra note 78, p. 110; Kymlicka, supra note 72, p. 36.
} 
policies targeting their traditional culture. Thus, individual and group rights must not be regarded as contradicting but as coexisting rights of utter importance for minority women's equal enjoyment of human rights. ${ }^{82}$ In this connection a differentiation between rights should be made within minority rights, where individual rights prevail over community interests in matters where these may conflict. However, as stated in the above, the minority rights framework has no such explicit differentiation between subject groups. Focus is on public minority matters (external discrimination against the groups as a whole), and gender-based discrimination of subjects within the group in society and internally within the minority communities is not accounted for. Thus, it can be difficult to redress Romani women's human rights problems within the anti-racial/minority rights approach as these also concern their gender and their position within their own families and communities. Here it is necessary to turn to the women's specific human rights framework.

\subsection{The Human Rights of Women}

The human rights of women have historically been a controversial issue in the international human rights community. Many states regard women's issues as domestic concerns and have shown reluctance towards ratifying international legal standards for women. ${ }^{83}$ Following the same line of argumentation as in state controversies over minority rights, it has been argued that ideally human rights belong to all human beings, women inclusive. However, history has shown general human rights law to be inadequate for the protection and advancement of women which across the world experience significant injustice in many areas of social life. Consequently, a number of international human rights standards specifically for women have been elaborated as complementary to general human rights law. ${ }^{84}$ The Convention on the Elimination of all Forms of Discrimination Against Women (1979/1981) with the Optional Protocol (1999) is the most important international legal instrument. ${ }^{85}$ The development of a special legal field on the human rights of women signifies that women are entitled to human rights for all as well as to specific human rights.

82) Johnsson, supra note 78, p. 39.

83) H. Charlesworth, 'What are "Women's International Human Rights"?', in R. J. Cook (ed.), Human Rights of Women: National and International Perspectives (University of Pennsylvania Press, Philadelphia, 1994) pp. 58-84, at p. 60; F. Gómez Isa, 'The Convention on the Elimination of All Forms of Discrimination Against Women and its Optional Protocol', in F. Gómez Isa and K. de Feyter (eds.), International Protection of Human Rights: Achievements and Challenges (University of Deusto, HumanitarianNet, Bibao, 2006) pp. 217-249, at p. 219.

84) The Convention on the Political Rights of Women (1952), the Declaration of the General Assembly on the Elimination of all Forms of Discrimination Against Women (1967), ILO Convention No.3 (1919).

85) Gómez Isa, supra note 83, p. 223. 
A reading of the substantive content of international human rights law relevant for women identifies non-discrimination and equal rights as the overall objective. ${ }^{86}$ As illustrated in the minority rights section above, the principle of nondiscrimination and equality is formulated as an accessory provision in most human rights instruments and it includes sex as a prohibited ground of distinction. Equal rights between men and women are also separately reaffirmed. ${ }^{87}$ However, only a few rights in general human rights law make explicit reference to women beyond these principles. These few rights concern marriage and family relations such as the right for men and women to marry freely and found a family. ${ }^{88}$ The International Covenant on Economic, Social and Cultural Rights (ICESCR) also ensures special protection for the mother in regards to childbirth. ${ }^{89}$ The European Social Charter has more elaborated rights for the special protection of employed women during pregnancy and maternity leave and for the economic and social protection of mothers and children. ${ }^{90}$

The rights set forward in CEDAW aim at substantive equality between men and women and cover more comprehensively than other areas of human rights law the issue of non-discrimination of women. Discrimination is defined in Article 1 of CEDAW and can be interpreted as including differences in treatment on the grounds of gender that intentionally, or unintentionally, places women in a disadvantaged position, that prevents society from recognising women's rights both in domestic and public spheres, and that prevents women from exercising the human rights and fundamental freedoms to which they are entitled. ${ }^{91}$ The rights target discrimination in all aspects of women's life, in political and public life as well as in social, economic and cultural life. ${ }^{92}$ Women are also ensured equality before the law and in marriage and family relations. ${ }^{93}$ Besides the prohibition of vertical discrimination, CEDAW targets horizontal discrimination (between private parties) (Article 5(a)). Seen together with other rights that call on the state to eliminate discrimination of women by persons, organisations or enterprises and to modify and abolish existing law, regulations, customs and practices which constitute discrimination against women, CEDAW

86) HRC General Comment no. 18: Non-discrimination, 10/11/1989; HRC General Comment no. 28: On the Equality of Rights between Men and Women (article 3), 29/03/2000, ICCPR/C/21/ Rev.1/Add.10.

87) ICCPR and ICESCR articles 3.

88) ICCPR, Article 23(2); ICESCR, Article 10(1); and ECHR, Article 12.

89) ICESCR, Article 10(2).

90) European Social Charter, Article 8 and Article 17.

91) Article 1 of CEDAW, and United Nations Office of the High Commissioner on Human Rights, Discrimination Against Women: The Convention and the Committee, United Nations, Human Rights Fact Sheet No. 22, 1995, available at <www.unhchr.ch/html/menu6/2/fs22.htm> (consulted 15 July 2009).

92) Articles 7-9 and 10-14.

93) Articles 15-16. 
targets discrimination in the private sphere such as personal status laws, norms of religious institutions, etc. ${ }^{44}$ Furthermore, the Convention approaches concerns shared by women such as trafficking for the purposes of sexual exploitation in prostitution, and rural women's advancement. ${ }^{95}$ In addition to the negative right of non-interference, the rights also establish positive obligations of the state to ensure elimination of discrimination, also through positive action/special measures. The obligations are both of means and of result. ${ }^{96}$

Although CEDAW covers the non-discrimination of women more broadly than other instruments in international human rights law and also provides women with special rights/measures, in practice there remains a problem of weak implementation. Women's rights remain a controversial issue in many states that have not ratified or made criticisable reservations to the Convention. ${ }^{97}$ By elaborating an Optional Protocol to CEDAW that establishes an individual communication procedure, the Committee has sought to strengthen its enforcement mechanism. ${ }^{98}$ Similar to the complaint mechanism under CERD, both individuals and non-governmental organisations (NGOs), on behalf of the individual who has suffered violations, can file complaints. Importantly, the Optional Protocol does not allow for reservations, a provision that will strengthen the protection of women's rights in the future. This places CEDAW more alongside other human rights treaties in the UN.

In regard to the minority women's issue, no women-specific rights refer to minorities. None of the CEDAW Committee's General Recommendations specifically concern minority women or make explicit reference to minority women, although being highly relevant for minority women. ${ }^{99}$ However, recent state reviews show that the CEDAW Committee is increasingly giving attention to the multiple discrimination of minority women for example in education, health care, in public and political life. ${ }^{100}$ In this connection it is important to highlight

94) Article 5(a) in conjunction with Article 2(e) and (f), and R. Cook, 'State Accountability Under the Convention on the Elimination of All Forms of Discrimination Against Women', in Cook, supra note 83, pp. 228-256, at p. 239.

95) Article 6 and Article 14.

96) Article 2 imposes an obligation of result, e.g. policy development for eliminating discrimination. Article 2 plus subsequent articles also establish obligations of means, e.g. the use of legislation or temporary measures to ensure the elimination of discrimination. Spiliopoulou Åkermark, supra note 47, p. 33.

97) Arguably, some of these reservations go against the object and purpose of CEDAW (CEDAW, Article 28(2) and Vienna Convention on the Law of Treaties, Article 19).

98) In CEDAW the Committee's mandate is limited to state reviews (Article 17), Gómez Isa, supra note 83 , p. 229.

99) Spiliopoulou Åkermark, supra note 47, p. 36.

100) E.g. referring to minority women: Communication No. 11/2006, U.N. Doc. CEDAW/ C/37/D/11/2006, Fourth Periodic Report of States parties: Netherlands, 10/02/2005, U.N. Doc. $\mathrm{CEDAW/C/NLD/4}$. See also referring to Roma women: Concluding comments of the Committee on the Elimination of Discrimination against Women: Czech Republic, CEDAW/C/CZE/CO/3, $25 / 08 / 2006$. 
the recent case Andrea Szijjarto v. Hungary under CEDAW's Optional Protocol. ${ }^{101}$ This case in fact concerned a Romani woman, who was subject of sterilisation in a Hungarian hospital without her full and informed consent. The Committee found a violation of the woman's human right to health information, nondiscrimination in the health sector and her right to family planning. ${ }^{102}$ The minority aspects of the case were, however, not approached. This is discussed further in the following section.

\subsection{Women's Rights as a Strategy to Redress "Internal" Discrimination}

A critical perspective on general human rights law shows how it is characterised by a prevailing masculine language that appears to operate with a dichotomy between public/private as being equal to male/female. ${ }^{103}$ The man is regarded as the provider of the household and thus placed in a public sphere of law, economics, cultural and political production (himself and his formulations in for example Universal Declaration of Human Rights (UDHR) Article 25). The woman on the other hand is presented as the household's care-taker, mother and spouse, and thus placed in a private sphere of home and family (in marriage and family provisions as in for example ECHR Article 12). Even though general human rights law does not exclude private life, the main emphasis is on protection of the individual in public life. This placing of woman's concerns in a private sphere along with an emphasis on public life-concerns has been criticised by various legal feminist scholars. They argue that it reflects an underlying andocentric structure in human rights law that fails to redress the systemic subordination of women in society as human rights violations, what is best exemplified by the weak implementation mechanisms and toleration of reservations to CEDAW. ${ }^{104}$ Thus, international human rights law can be argued to be constitutive and reproductive of a maledominant discourse where the public/private divide becomes a screen to avoid women's issues.

The legal provisions of CEDAW and the Committee's interpretations hereof untraditionally place women's concerns within public view. A focus is laid on women's concerns in contexts beyond those of motherhood and marriage.

\footnotetext{
101) A. S. v. Hungary, Communication No. 4/2004, U.N. Doc. CEDAW/C/36/D/4/2004. Besides this case CEDAW has dealt with five communications under the Optional Protocol: B.J. v. Germany, Communication No. 1/2003, U.N. Doc. CEDAW/A/59/38/D/1/2003; A.T. v. Hungary, Communication No. 2/2003, U.N. Doc. CEDAW/C/32/D/2/2003; Dung Thi Thuy Nguyen v. The Netherlands, Communication No. 3/2004, U.N. Doc. CEDAW/C/36/D/3/2004; Rahime Kayhan v. Turkey, Communication No. 8/2005, U.N. Doc. CEDAW/C/34/D/8/2005; Constance Ragan Salgado v. United Kingdom of Great Britain and Northern Ireland, Communication No. 11/2006, U.N. Doc. CEDAW/C/37/D/11/2006.

102) Articles 10(h), 12 and 16(1)(e) of CEDAW.

103) Cook, supra note 94, p. 242; Charlesworth, supra note 83, p. 69.

104) Charlesworth, supra note 83, p. 59; Cook, supra note 94.
} 
Violations of women's rights are interpreted within a larger rights framework such as violence against women as falling under the provisions on degrading and inhuman treatment. ${ }^{105}$ The language of CEDAW goes beyond the traditional gender-neutral formulated equality-norm and establishes a legal norm that recognises how women's disadvantaged positions in society requires special measures in order to have de facto equality. ${ }^{106} \mathrm{CEDAW}$ can thus function as a legal tool for minority women to comprehensively redress the gender-based discrimination they experience in society. The empirical examples showed how gender is a significant factor in Romani women's human rights concerns. They are to a higher degree than male Roma excluded from many areas of social life such as education, health care, employment, political participation, access to public spaces when wearing their traditional dress, etc. They also experience other forms of violence than Romani men related to their gender and ethnic origin in combination, such as sexually abusive name-calling and assaults, rape and coercive sterilisation.

Furthermore, the human rights of women challenge a traditional human rights focus which concerns the relationship between the state and the individual. ${ }^{107}$ It obliges the state to interfere both in matters of vertical and horizontal discrimination of women. This includes legally tolerated customs and practices of national institutions and communities that discriminate women such as personal status laws where women have a subordinate position in marriage-relations, divorce, property, etc. ${ }^{108}$ In the case of Romani women, it could include patriarchal community customs such as deliberate non-education of women, early and arranged marriages, virginity cults, etc. Thus, human rights of women can serve as legal tools to redress internal discrimination, namely discrimination that minority women experience internally in their own communities that conflict with their individual rights as women. ${ }^{109}$ In other words, CEDAW can be regarded as a comprehensive legal instrument to redress the gender-based discrimination Romani women experience in society and also internally in their own communities. In this regard, the women's framework has another function additional to that of presenting the state with human rights obligations. It namely becomes a vital instrument to promote and give legal weight to a struggle for genderequality internally in Romani families and communities. In this double-function, in litigation and as legal basis in an internal feminist struggle, the human rights

\footnotetext{
105) ICCPR, Article 7.

106) CEDAW, Article 1 in conjunction with Article 3 and Spiliopoulou Åkermark, supra note 47, p. 31.

107) This also signifies that CEDAW challenges the traditional public/private division in human rights law where cultural and religious rights have been regarded as private freedoms outside legal regulation. Charlesworth, supra note 83, p. 74.

108) CEDAW, Article 2(f) in combination with Article 5(a).

109) Cook, supra note 94, pp. 239-240.
} 
of women approach covers more extensively than minority rights the genderbased concerns of minority women.

CEDAW is to a large degree untested water for the litigation of minority women's concerns, with only one minority women case before the recent complaint mechanism, namely the recent Andrea Szijjarto v. Hungary case concerning coercive sterilisation of a Romani women. However, this single case is path breaking as it is an example of how women's human rights can indirectly serve against the systematic discrimination that many Romani women experience in society. The Committee found a violation of the woman's human right to health information, non-discrimination in the health sector and her right to family planning. It thereby redressed the discrimination and violation of physical integrity that many Romani women experience in the health sector. It furthermore targeted the lack of information that minority women often experience due to language barriers. It underscored the state's obligation to eliminate discrimination and provide accessible and understandable information for all. ${ }^{110}$ This innovative use of the CEDAW proves that the women's rights framework could become a useful legal avenue for the litigation of future minority women cases. The case can be seen as indirectly benefiting the woman's minority rights. However, herein lies the pitfall in the $A S$ v. Hungary case, namely that that only the gender-aspects were approached and the ethnicity/racial aspects were entirely neglected. Structural discrimination of Roma (in this case in Hungary) because of their ethnic origin is a key part of the problem of coercive sterilisation of Romani women. Coercive sterilisation is not targeted randomly at all women in the given countries where these cases have occurred but specifically at women who are at additional disadvantages due to multiple discrimination against them. ${ }^{111}$ In the case of Romani women coercive sterilisation is a consequence of structural discrimination against Roma as a minority group combined with that of gender-based discrimination (and often the low social status of the woman) which together enhance the vulnerability towards rights violations of the women in question. Thus, ethnic discrimination aspects necessarily have to be taken significantly into account. It is in this regard that the, although innovative, women specific human rights approach comes short to redress the concerns of Romani women and minority women in general. CEDAW as a legal text has no references to other forms of discrimination than gender-based discrimination. Focus is on women as a whole, the only exception being a specific right for rural women. No rights concern minority, indigenous, migrant or refugee women. Herein lays a weakness in this Convention. Recent state reviews in the CEDAW Committee show a growing attention to multiple discrimination of minority

110) A. S. v. Hungary, Communication No. 4/2004, U.N. Doc CEDAW/C/36/D/4/2004.

111) Throughout history women with disabilities have been subject to unlawful coercive sterilisation as have also women with indigenous ancestry and ethnic minority women. 
women, including particular attention to Romani women. However, so far no larger steps have been made to redress the problem of multiple discrimination, neither in the form of developing new legal standards or jurisprudence, nor in form of elaborating a General Recommendation on minority women. Thus, while the human rights of women framework can be important for the future litigation of minority women's experiences of gender-discrimination also internally in minority communities, it does not fully include the ethnic dimension necessary to redress sufficiently many other concerns of minority women. Here, minority women need additionally to turn to the minority rights framework to find legal solutions to the external discrimination they experience as members of an ethnic minority.

\subsection{Closing the Analysis: Romani Women as Subjects in Legal Discourses}

The analysis of women and minority human rights illustrates how they have a disadvantage in common, namely that they risk isolating subjects from other areas of international human rights law. The elaboration of special frameworks for specific groups as minorities and women provide protection where general human rights law is inadequate. However, it must be borne in mind that within this process of special rights protection ensured in separate treaties/declarations exists a risk of reproducing a tendency within human rights law of isolation (ghettoisation) of subjects of rights in "special" categories with special measures. ${ }^{112}$ This indirectly opens a door for reluctant states to avoid responsibility either by claiming lack of resources to deal with the "special" problem, avoiding ratification, or presenting significant reservations as have been seen with regard to CEDAW and its Optional Protocol. Thereby, an inherent paradox appears within the framework on special rights. The very measures meant for inclusion and protection of groups traditionally excluded from the law may in practice unintentionally reproduce the isolation of the group within international human rights law. This is a problem that becomes even more complex in the case of Romani women and minority women in general. On the one hand minority women fall into two categories of specific rights, minority and women's rights, in addition to general human rights law. On the other hand, they are often excluded from these rights discourses because the women specific law does not specifically address the minority issue and vice versa, and general human rights law has vague provisions on women and minorities. Consequently, minority women on many occasions become subjects out of place within international legal human rights. This limits Romani women's possibilities for finding legal redress for the human rights violations they experience, where

112) Charlesworth, supra note 83, p. 66. 
gender and ethnicity are complexly interrelated grounds and where discrimination has both internal and external dimensions.

With no specific rights or jurisprudence that interrelate race/ethnicity and gender issues, Romani women can try to turn their apparent double exclusion from the law into a double recognition, by addressing different aspects of the discrimination they experience under various areas of human rights law. The analysis presented insight into positive steps that have been made in this direction and what further steps could be made. It showed that minority women could use antiracist and minority rights to redress external discrimination and women's human rights to redress gender-based discrimination in society and internally in their own communities. In this regard, particularly CERD and CEDAW appear to be potential legal avenues for the litigation of Romani women's cases. This can be argued, although it is criticisable that the treaty bodies only address multiple discrimination in recent state reviews and not in their jurisprudence where categories of gender and race are still separated. Examples of how human rights law could be used innovatively for the litigation of Romani women's cases are given in a report developed by the Center for Reproductive Rights in New York and Centre for Civil and Human Rights of Poradna in Slovakia. In this report it is argued that coercive sterilisation of Romani women is a violation of a broad range of human rights, namely the right to equality and non-discrimination, the right to health, the right to physical integrity, prohibition of torture and inhuman and degrading treatment, the right to reproductive self-determination, the right to informed consent and the right to information. It was also argued that it could constitute a crime against humanity and thus fall under the scope of the International Criminal Court (ICC) if it is proven that the crime was carried out with the "intent to destroy, in whole or part" a targeted ethnic group. ${ }^{113}$

Combining various legal discourses on human rights from general and specific areas of human rights law to address particular forms of discrimination can thus serve as a strategy to increase the justiciability of the human rights violations Romani women experience in contemporary society. However, this strategy never directly targets the causes for their human rights concerns. It does not address the full aspects of the situation which has led to the rights violations against the person in question. Furthermore, this form of strategic manoeuvring is difficult within a human rights framework which has shown to be conservative in nature and operate rather stringently with separated rights categories. It is an even greater challenge to strategically combine legal aspects for a group of minority women, such as Romani women, that do not have the same access to education, information, legal assistance and economic resources as the majority.

113) Center for Reproductive Rights in New York and Centre for Civil and Human Rights of Poradna, supra note 36, p. 96. 


\section{Romani Women and International Human Rights Politics}

Litigation is only one strategy that Romani women can use to confront the discrimination and human rights violations they experience. There is a large and complex political sphere around human rights that has shaped the existing body of law. Thus, human rights activism is about litigation but also about influencing agenda-setting and institutional developments in international, regional and national political settings.

Both minority rights politics and politics surrounding the human rights of women can be approached as identity-political discourses. Identity politics are political processes where demands are made that social and political institutions acknowledge and accommodate differences in ethnicity and race, gender and sexuality. Thus, identity politics emphasises differences, and denies that for example women and minorities should re-shape identities to fit dominant (majority and male) standards. ${ }^{114}$ The following analysis illustrates how identity politics is central to the barriers that Romani women experience within international human rights politics. It also highlights the possibilities that Romani women have of using and influencing the political framework.

\subsection{Ethno-politics for Minority Rights}

The strongest focus in the global Romani movement is on what can be termed "ethno-political" projects. Focus is on the external status of the group as a nation or minority in society and on the protection and promotion of the group's distinctive identity and culture. Thus, ethnicity is the basis of claims for equal rights and confrontation is made with racist/ethnic-discriminatory political regimes. In this political project, the collective ethnic identity as Romani is put forward and other identities (as worker, woman, elderly, etc.) are often downplayed. Through such a process of unification around minority politics, Roma have entered official categories as minorities. Thus, the primary focus on minority group concerns within Romani politics cannot be understood in isolation from the international political contexts which largely address Romani issues within a minority rights framework. The last 15 years have shown a growing body of reports and political initiatives on the Roma at UN and European level. In particular the drawing of new European political boundaries after 1989 and the inclusion of CEE member states into the EU after 2004 opened for debates on the critical human rights and development situation of Europe's largest ethnic minority. Consequently, a broad range of Romani specific reports and programmes has been elaborated within the

114) G. Warnke, 'Race, Gender, and Antiessentialist Politics', 31:1 Journal of Women in Culture and Society (2005) p. 94, available at <www.journals.uchicago.edu/SIGNS/journal/issues/v31n1/310108/ 310108.web.pdf > (consulted 15 July 2009); Kymlicka, supra note 72, p. 9. 
CoE, EU and Organization for Security and Co-operation within Europe (OSCE). The Decade of Roma Inclusion (2005-2015) is the largest initiative of this sort, which has become a global objective aimed at social inclusion of Roma through development of international benchmarks and national action plans with special measures for minority inclusion. ${ }^{115}$ By organising and entering into such a minority category, the Roma have gained corresponding legal and political power to confront the (external) discrimination and violation of human rights that they experience in society.

Romani women benefit from this development together with the larger Romani community and use the acquired political position to confront the discrimination and violations of human rights they experience as Roma. However, the criticism Romani women make of patriarchal traditions of early marriages, virginity cults and silencing of sexuality and domestic violence is by some Romani activists regarded as a threat to the ethno-political project. Some argue that the gendercritique takes the attention away from external problems of ethnic discrimination and instead focuses on internal problems that can damage the Romani human rights project. They fear losing political ground when presenting a more heterogeneous political agenda, with different subject concerns and duties not only towards the external (state and society) but also towards the internal (the group itself). Others fear that the focus on internal problems can damage the image of "Romani culture" and that negative attitudes towards Roma may gain new ground and cause more racism and discriminatory laws and policies. ${ }^{116}$ This dilemma is relevant not only for Roma, but also for many other minority and anti-racist organisations. They experience having to weigh their interest in avoiding issues that might reinforce negative public perceptions of the group against the need to acknowledge and address intra-community problems. ${ }^{117}$ In effect the complexities that surround minority women are often neglected.

However, possibilities for approaching other identity concerns within the minority political approach appear to be gradually opening up. At international level, there is increasing focus on the particular problems that Romani women share. Particularly the EU has been progressive in holding conferences and elaborating comprehensive reports on the issue. ${ }^{118}$ The main focus of the international initiatives is on Romani women's multiple disadvantages in the areas of health care, education and economic and political participation. Although criticised by many Romani activists, many other Romani activists also are positive towards the challenging approach of the women activist and support their criticism of some

115) <www.romadecade.org/index.php?content=1> (consulted 15 July 2009).

116) ERRC Roundtable, supra note 31, responses by Demirovski and Sztojka at pp. 31-32 and 33-43.

117) Crenshaw, supra note 7, p. 1253.

118) Examples are: EUMC, supra note 34, and BVIS, supra note 32. 
patriarchal traditions: 'In recent years, Romani women have given voice to their problems (...) Roma feminism is a part of the development of Roma rights in general, and Romani women are fighting for an end to their inequality." 119 These signs of change within the minority approach reflect new possibilities for discussing Romani women's gender-based concerns also within their own communities although this is a change which still requires much time. Romani women's activism is about minority rights but also about women's human rights. They engage in a feminist project aimed at their own communities and families to change gender-relations and cultural practices that subordinate women. Here, they can find support within international political initiatives concerning the human rights of women.

\subsection{Gender-politics for Women's Human Rights}

Where the global Romani movement is argued to present an ethno-political project, the global women's movement can be seen as presenting a genderpolitical project. Gender is the basis of claims for non-discrimination and equal rights and opposition is made to gendered political regimes. In this political project, the identity brought forward is the individual female identity and other identities such as the ethnic group identity or worker's identities are downplayed. This objective stands in contrast to the identity politics of the minority movements that emphasised the recognition and equality of a collective ethnic identity. The global women's movement also operates with a concept of collective identity, in form of a somewhat uniform global "woman" identity, where specific values and concerns are set forward as relevant for all women. ${ }^{120}$ Particular feminist symbols are used as symbols to underscore the unity of women. ${ }^{121}$ Thus, similar to the ethnic community, particular values and symbols are set forward to mark the boundaries around the gendered community. However, as was the case with the ethno-political project in the Romani movement, this exclusion of other issues from the gender-political project cannot be understood in isolation from the international political contexts that the global women's movement interacts in. Human rights initiatives for women in the UN and European intergovernmental organisations have traditionally been single-issue approaches to gender-aspects. Through a process of unification and uniformity around genderpolitics, the global women's movement has gained a strong voice in world politics and pressed for the recognition of women's concerns as being human rights

\footnotetext{
119) ERRC Roundtable, supra note 31, response by Ivanov at p. 36.

120) Charlesworth, supra note 83, p. 62.

121) P. Antrobus, The Global Women's Movement: Origins, Issues and Strategies (Global Issues, Zed Books, London, 2004) p. 21; B. Anderson, Imagined Communities: Reflections on the Origin and Spread of Nationalism, new edition (Verso, 2006) p. 81.
} 
concerns that require international and national measures. Minority women can use the global gender-political approach in their own feminist projects to change patterns of gender-discrimination and inequality in society and within their own communities.

As also seen with the ethno-political project, this emphasis on grouphomogeneity within the global women's movement leaves little room for internal variations and other political demands. This was evident in the historical exclusion of other issues such as race/ethnicity and class. However, in the 1990s the critique for this exclusion, made by feminist legal scholars and women's organisations in particular from Latin America and South-East Asia, gained ground. The critique was that the global women's movement and the international community had a "single-issue approach" only to gender and neglected other barriers to women's advancement, such as race, ethnicity and class. ${ }^{122}$ In the light of their historical experiences with imperialism, racism and religious patriarchal social structures, these activists found it impossible to separate issues of gender, race, ethnicity and class when fighting against the structural domination of women: "There is no such thing as a single-issue struggle because we do not live single-issue lives." 123 In the contemporary political context of human rights, there is a broad recognition of the discrimination that many women in society experience on multiple grounds, thus giving enhanced attention to the situation of indigenous women, minority women, migrant and refugee women and many others. The focus on the gendered identity is by some organisations thereby only one component of a larger project for social transformation. This project requires change of all structures that subordinate women, meaning structures that link to gender and also to race/ ethnicity and class relations. Particularly the racial and gender-based violence that minority women experience has often been noted and in a few instances reference has been made specifically to Romani women. ${ }^{124}$ Romani women can benefit from this changing focus within the global women's movement. In particular the women's organisations in Latin America, Asia and other regions which emphasise multiple discrimination issues are new political alliances that could be explored by Romani women to increase the political attention to the problems of discrimination on multiple grounds that they experience. Such alliances need, however,

122) Antrobus, ibid., p. 15; C. T. Mohanty, 'Introduction: Cartographies of Struggle: Third World Women and the Politics of Feminism', in C. T. Mohanty, A. Russo and L. Torres, Third World Women and the Politics of Feminism (Indiana University Press, 1991) pp. 1-43, at pp. 10-15.

123) A. Lorde in Antrobus, ibid., p. 15.

124) R. Coomaraswamy, Report of the Special Rapporteur on violence against women, its causes and consequences, Integration of the Human Rights of Women and the Gender Perspective: Violence Against Women, E/CN.4/2003/75/Add.1, 27 February 2003, submitted in accordance with Commission on Human Rights resolution 2002/52 Addendum 1, International, regional and national developments in the area of violence against women 1994-2003, available at <www.unhchr. ch/Huridocda/Huridoca.nsf/0/e29d45a105cd8143802568be0051fcfb/\$FILE/G0011334.pdf> (consulted 15 July 2009). 
to be consistent and strong to give more voice to Romani women and ensure actual realisation of projects, and this is not the case today. As of today, the only larger initiative for Romani women is the Romani Women's Programme under the OSI Women's Programme (1999). And even this programme has today very limited activities.

\subsection{Closing the Analysis: Romani Women as Subjects in Political Discourses}

The analysis of the two political discourses on minority rights and women's human rights illustrate a grey area in human rights politics, where the subjects who experience discrimination on interrelated grounds often experience neglect. It is in this intra-group grey area that minority women, and in this case Romani women, are located.

Many scholars and activists regard feminist and minority/indigenous politics as irreconcilable. Feminists criticise minority and indigenous organisations for being strict cultural relativists, who fight to preserve cultural traditions even at the expense of individual rights of persons from within the group. Vice versa is often argued by many minority/indigenous groups. ${ }^{125}$ In legal terms, this conflict is often manifested as the before discussed conflict over collective and individual rights. However, there are many similarities between the women's and minority political discourses that are often overlooked in this controversy. Both challenge traditional approaches within human rights with political and legal claims for the inclusion of identity-specific perspectives (gender and minority perspectives). They emphasise differences in gender and ethnicity as ground for recognition and special protection within politics and law. These similarities indicate that the political approaches could be used as mutually reinforcing instead of conflicting. Romani women's activism in fact exemplifies this argument.

The empirical section of this article showed how many Romani women activists present a political approach that combines both ethno-politics and genderpolitics. They emphasise their multiple identities and claim for attention to the particular concerns that they have, by being both minorities and women and in some instances also poor. In their political project Romani women do not make one identity exclusive of the other but instead approach their identities as intrinsically related and mutually reinforcing. This is the essence of the (identity) political approach of Romani women activists, who support both the agenda of the global Romani movement and of the global women's movement. Thus, the intention is not, as it has been suspected by other activists, to separate from the global

125) See discussion on this issue in E. Brems, 'Enemies or Allies? Feminism and Cultural Relativism as Dissident Voices in Human Rights Discourse', in B. B. Lockwood (ed.), Women's Rights: A Human Rights Quarterly Reader (Johns Hopkins University Press, 2006) pp. 101-129. 
Romani movement and engage only in a feminist project. ${ }^{126}$ In fact, Romani women have a two-fold political project. One targets the external and underlines the state's obligation to ensure their equal human rights and development as minorities in majority society and as women in a male-dominated society. The other political project targets the internal (the Romani community and family). This is a feminist struggle for the equal rights and opportunities of men and women that requires dialogue and change of patriarchal traditions which risk violating the individual rights of the women and girl child. In this project, obligations are placed on their own community and family members to abandon gender-discriminatory traditions. Obligations are also placed on the state to interfere in matters where traditional practices violate the individual rights of the Romani woman.

Thereby, a debate is opened on the relationship between cultural traditions and modernity that is often perceived as an irreconcilable conflict between minority/ indigenous collective rights and individual rights (as for example women). Instead of advocating a choice between the two, the women call for protection of Romani culture while changing certain cultural practices to ensure the equality of women and respect of the individual rights of all members within the cultural group. ${ }^{127}$ This way, the women present an approach that has a dynamic view on culture and identity as multiple, overlapping and changeable. This approach stands in contrast to the essentialised notions of identity often expressed in the global Romani movement and in the global women's movement and can serve to reconcile the two political discourses.

In their political engagement in two settings, Romani women not only invoke women's rights in a minority forum, but they in fact also invoke Romani minority rights in women's fora. This way the ethno-political Romani project can enter new NGO settings. Human rights of women could thus be a potential political strategy to advocate minority rights also. This strategy is so far untested in the global Romani movement but has been used by indigenous peoples' organisations. ${ }^{128}$

By way of closure, the two analyses opened for insight into how contemporary international human rights law and politics serves to address Romani women's human rights concerns. The barriers and possibilities which they do and can experience when turning to the international framework for legal and political support were highlighted. On this basis it is necessary to develop the discussion a step further. The limitations that minority women experience within international human rights law and politics present a concern that reaches beyond that of technical applicability of the law. It is also a normative

126) IRWN, supra note 6, pp. 7-8.

127) ERRC Roundtable, supra note 31, article by Xemajli at p. 30.

128) See <www.indigenouswomen.org/aboutus2.htm> (consulted 4 July 2007). 
concern. The human rights system is a value-based international system aimed to ensure the protection of the life and human dignity of all persons through international standards and procedural rules. When practice shows that a subject group, such as minority women, fall out of the scope of protection or experience limited protection, this questions the all-inclusiveness or allapplicability of the rights framework. In other words, the subject of minority women may be regarded as a challenge to the universality of the human rights project. Thus, in addition to the investigation of the challenges that the law/ politics present to Romani women, it is also important to investigate the challenges that the issue of Romani women, and of minority women in general, presents to the universal human rights project. This analysis is developed in the following. It is discussed how the concept of "intersectionality" can serve to frame new approaches to issues concerning minority women and thus strengthen the perspective on their particular human rights concerns within international human rights.

\section{Minority Women as a Challenge to the Human Rights Project}

Romani women activists have on several occasions expressly criticised the universality of human rights;

Roma women's issues represent a challenge for both women's and Roma movement discourses. Roma women's agendas call into question the assumed universality of the human rights discourse for those involved in defending human rights for both women and Roma. ${ }^{129}$

It is interesting that the women in their creative agency for political recognition and legal protection within human rights at the same time question the fundamental principle of the human rights project, namely its universal validity. In this section, the meaning of this universality critique is analysed as part of an investigation of the challenges that the subject of Romani women, and minority women in general, presents to the international human rights project. On this basis, a discussion is made on how to develop contemporary international human rights discourses to ensure a stronger inclusion of minority women's issues.

129) IRWN, supra note 6, p. 8. See also N. Bitu: "Then I started to put forward questions on my own declared beliefs and public discourse. Do I really believe in the universality of human rights? I was thinking: I am an activist fighting for the rights of Romani people, but what about other types of rights? Do I really believe in them or are my personal convictions so far from that, that I pray in public until the point where I start to have double discourse?" N. Bitu in 4 Roma Rights Quarterly Journal of the European Roma Rights Centre (2003) at <www.errc.org/cikk.php?cikk=1348> (consulted 4 June 2007). 


\subsection{Questioning Universality from a Perspective on Human Dignity}

The debate on the universality of human rights is an ongoing debate that gained significant ground during the 1970s. ${ }^{130}$ The term "universality" of human rights is attributed several different meanings and usages by scholars and laymen. ${ }^{131}$ A dominant perspective within the universality debate is the cultural relativist stance, where it is argued that the diversity of people, in their culture and historical realities, makes it impossible to design a universal human rights project. Values are seen as culturally relative, and therefore Asian, Middle Eastern, African, and other values are argued to be remotely different from the Western liberal norms that form the legal framework of human rights. ${ }^{132}$ The subject of minority and indigenous peoples has frequently been discussed within the cultural relativist stance. It is argued that human rights are legally formulated values that do not apply to the particular realities and demands of minorities and indigenous peoples and may even pose a threat to their traditional cultures. In this perspective, human rights are treated as foreign norms and made secondary to other particular normative frameworks. ${ }^{133}$

The cultural relativist stance has been criticised by several scholars and practitioners within the human rights field. ${ }^{134}$ One critique presented by the Danish philosopher George Ulrich is that the opposition between Western and nonWestern values is essentially critical as it is based upon a fictive image of cultures as homogenous and static. ${ }^{135}$ Cultures do not have fixed normative standards but are to the contrary in constant processes of formation where values and norms are exchanged, adopted or rejected across national/community borders. The empirical discussions in the previous sections illustrate this. It was highlighted how identities, meanings and norms are dynamic entities constantly negotiated and appropriated by social actors in relation to their changing social and historical circumstances. The phenomenon of global human rights activism is itself an example of this on-going articulation where social actors identify with human

130) K. Hastrup, 'The Quest for Universality: An Introduction', in K. Hastrup (ed.), Human Rights on Common Grounds: The Quest for Universality (Kluwer Law International, The Hague, 2001) pp. 1-25.

131) Recent literature often presents a normative conception of universality, as general and worldwide applicability or all-inclusiveness of human rights, signifying that human rights are rights that belong to all simply because they are human. E. Brems, Human Rights: Universality and Diversity (Kluwer Law Intenational and Martinus Nijhoff Publishers, The Hague, 2001) pp. 4-16 and J. Donnelly, in same book, at p. 4.

132) Brems, ibid., pp. 23-25.

133) Ibid., p. 27.

134) Ibid.; Hastrup, supra note 130; G. Ulrich, 'Universal Human Rights: An Unfinished Project', in Hastrup, supra note 130, pp. 195-225.

135) Ulrich, ibid., p. 196. See also M. Kjærum, 'Universal Human Rights: Between the Local and the Global', in Hastrup, supra note 130, pp. 75-89, at p. 76. 
rights in different ways across national/community borders. It would therefore be wrongful to argue that human rights are values foreign to Romani women activists as they are often at the very heart of their advocacy. Therefore, the activist's criticism of the universality of human rights must be interpreted differently. Ulrich argues that the universality of human rights must be approached within a practical realm. It is not a question of whether human rights are rights that belong to all human beings in theory, but a question of whether they in reality (practice) are implemented and interpreted so that they are relevant for all human beings:

$[T]$ o be valid human rights standards must be relevant and constructive in the contexts in which they are applied. They must, in other words, provide a framework within which it is possible to find solutions to the exigencies of a given social and historical moment. ${ }^{136}$

Within this approach, the universality of human rights is not a moral project that can be demonstrated and settled once and for all. To the contrary the validity of human rights is "an on-going test which defines the universality of human rights essentially as an unfinished project". ${ }^{137}$ A similar approach to the practical validity of norms is made by Habermas who defines norms to be valid when all possible affected persons agree to them as participants in rational discourses. ${ }^{138}$ Thus, the universality of human rights is an on-going project, where interpretations and development of human rights standards must continuously be made so that they respond to the empirical realities.

In this line of argumentation the concept of human dignity can be seen as key in the legitimacy of universal human rights. "Human rights should not be perceived as ends which have to be achieved but as forceful means to protect human dignity..."139 The legal scholar Morten Kjærum here underlines how human rights is a project for implementing international standards to ensure the adequate protection of the human dignity of all individuals. According to the legal scholar Christina Johnsson, the principle of human dignity is frequently used as a justification of human rights in public international law. This is evident in for example the UN Charter ("Faith in the dignity and worth of the human person") ${ }^{140}$ and in UDHR ("recognition of the inherent dignity and of the equal and inalienable rights of all members of the human family"). ${ }^{141}$ Johnsson illustrates how human dignity is often regarded as including inviolability of personal integrity

\footnotetext{
136) Ulrich, ibid., p. 221.

137) Ulrich, ibid., p. 221. Ulrich terms the contextual validation of human rights the "test of pertinence".

138) J. Habermas, Between Facts and Norms: Contributions to a Discourse Theory of Law and Democracy (Polity Press, UK, 1996) p. 107.

139) Kjærum, supra note 135, p. 83.

140) UN Charter, preambular paragraph 1, and Johnsson, supra note 78, p. 91.

141) UDHR preamble, and Johnsson, supra note 78, p. 91.
} 
and personal autonomy. ${ }^{142}$ The principle of inviolability entails that all human beings have an intrinsic value in themselves and should be treated with respect for their personal integrity. The principle of personal autonomy sets out that all human beings must have the possibility to make their own decisions and have some degree of autonomy over their own destiny. Thus, human dignity entails that all human beings have a value in themselves and "should be treated according to their decisions, intentions and expressions of consent, and that these must be taken as antecedents of obligations and liabilities". ${ }^{143}$

The previous sections illustrated how many Romani women experience a violation of their personal integrity and personal autonomy. Denial of use of their mother tongue or traditional dress in public, exclusion from political participation, lack of adequate information to ensure their full and informed consent in matters that concern them, segregation in schools and hospital wards, gender and racially motivated physical and verbal assaults, and last the extreme cases of coercive sterilisation are various examples. Also within their own families and communities these principles may be violated in matters where the girl/ woman is limited/prevented from education and employment of her own choice, where she is requested to follow traditional practices of early and arranged marriages and virginity cults, or where traditions for silencing domestic violence prevent her from acting against the abuse she experiences within the family. In other words the basic principles of personal integrity and autonomy central to human dignity are weak in the lives of these Romani women: "The multiple discrimination and social exclusion of Romani women exacerbates the cycle of poverty into which many of them are born, and deprives them of their human dignity." 144

It is in this connection that the women activists' critique of the universality of human rights can be understood. The majority of Romani women's activists do not question the normative idea of universal rights per se - in fact the majority support it. What they are critical towards is the contemporary universal realisation of human rights because they feel that they are not adapted and implemented in ways that benefit them. Thus, the next step is to investigate what changes can be made to the on-going realisation of human rights, in order for them to have increased relevance in the lives of Romani women as a normative legal framework that protects their human dignity. This is the focus in the following section, where it is argued that the concept of "intersectionality" can serve to frame a new focus on minority women and thus strengthen the international attention to their human rights concerns.

142) Johnsson, supra note 78, 2002 pp. 91.

143) Nino in Johnsson, supra note 78, p. 93.

144) European Parliament, supra note 21, p. 10. 


\subsection{Intersectionality as Framing Concept}

The concepts of intersectional discrimination and multiple discrimination were elaborated in the late 1980s, particularly by Kimberlé Crenshaw. According to Crenshaw intersectionality can be defined as the meeting point and overlap of roads of racial, gender, class and other forms of discrimination. These roads structure the social, economic and political terrains, and it is at the heart of their intersection that minority women are located. ${ }^{145}$ Thus intersectional discrimination and intersectionality are concepts that describe the situation where several grounds of discrimination operate at the same time and cause a violation of the human rights of minority women. A further appropriation of the concept into contemporary human rights discourses can thus bring to attention often neglected complexities that surround the issue of Romani women.

The approach to intersectionality within international human rights must, however, be comprehensive. Since it was first introduced in the 1980s "intersectionality" has been discussed and elaborated upon by a range of other scholars and organisations ${ }^{146}$. However, little practical consequences have been seen on the issue, either with regard to law and policy development, or with regard to programming, research and data collection.

In order to enable actual changes within the contexts of minority women, the approach to intersectionality must be practically implemented in the work of human rights bodies and organisations, and not remain primarily for theoretical discussion. This is a frequently problem with the adoption of new framing concepts, not only within the field of human rights, but also in fields of development, peace and security and other international areas where ideals and realities (theory and practice) can be difficult to match. One step in the direction of establishing intersectionality as a useful concept to frame future approaches to the human rights of minority women is to have a comprehensive understanding of the concept that covers the different forms of intersectionality in effect in a minority women's context. These can broadly be categorised as: structural intersectionality, political intersectionality and representational intersectionality. ${ }^{147}$ This is the start of framing a context for particular solutions to the complexities surrounding persons who experience discrimination on multiple grounds.

145) Crenshaw, supra note 7, pp. 1241-1245 and Crenshaw in MRG, supra note 9, pp. 11 and 33. This thesis is inspired by Crenshaw's theory and develops it further to serve within a minority women's context, whereas Crenshaw focuses on black women in the United States.

146) E.g. European Commission, Tackling Multiple Discrimination; T. Makkonen, Multiple, Compound and Intersectional Discrimination: Bringing the experiences of the most marginalized to the fore, Institute for Human Rights, Åbo Akademi University, 2002; UN General Assembly Report of the World Conference against Racism, Racial Discrimination, Xenophobia and Related Intolerance, Durban, 2001, Declaration No 2.

147) Crenshaw, supra note 7, p. 1244. 
Structural intersectionality takes place when various discriminatory or subordinating structures in society intersect (cross-cut or interrelate) and cause a multifaceted disempowerment of the person in question. For example, the availability and accessibility of institutional mechanisms for redress are frequently seen as affected by the interrelation of gender and race, for example in social service offices, justice institutions and in other state institutions that deal with minority women. ${ }^{148}$ This is evident in Romani women's access to justice cases. The empirical section illustrated how some states, because of racial/ethnic biases in the justice institutions, do not exercise due diligence in investigating and persecuting cases where Romani women are victims of rape or other physical abuse. ${ }^{149}$ In these instances one disadvantage combines with another, that of gender-based discrimination with that of ethnic discrimination, and causes a multiple violation of the rights of the Romani woman in the form of sexual violence (rape) with no consequential access to justice. In some of these cases both acts of discrimination have clear racial and gender dimensions, as racially motivated rapes with no consequential access to justice. In other cases only one form of discrimination is present in each act but the acts are interrelated such as spousal rape (genderbased) with no consequential access to justice due to ethnic discrimination. ${ }^{150}$ Other examples of situations where gender and ethnicity interrelate and cause multiple disempowerment of Romani women and Romani girls were seen in the areas of health care, education, social services and employment.

A strong example of intentional intersectional disempowerment is coercive sterilisation of Romani women, which is still reported in the Czech Republic and Slovakia. Here, omission and insufficient national laws within the area of criminal law and sterilisation has many times left these cases in impunity. ${ }^{151}$ Intersectional discrimination can, however, also be unintentional. This is seen when laws/policies or institutional rules are counterproductive in cases where gender and race/ethnicity combine. Crenshaw provides examples of such in cases from the United States where shelters turn non-national language speaking women (minority, migrant, refugee women) away for lack of bilingual personnel and resources. These women are thereby left without the protection that the shelters are intended to provide. ${ }^{152}$ Importantly, structural intersectionality not only takes place at institutional levels but also within the broader contexts of society where the interrelation between gender and ethnicity causes disempowerment of Romani women in the form of harassment or denied entry into restaurants and

\footnotetext{
148) MRG, supra note 9, p. 13.

149) Asylum Aid, supra note 28, p. 57.

150) A third aspect of gender-based discrimination that may be present in the justice institution is non-investigation of domestic violence or spousal rape because they are regarded as private matters.
}

151) Kopalová, supra note 40, pp. 27-30.

152) Crenshaw, supra note 7, pp. 1249-1251. 
shops when wearing their traditional dress, sexual assaults, abusive name-calling, non-employment, etc.

Political intersectionality is another problem to approach. It is seen how Romani women are often situated within two political groups that pursue separated or in some cases even conflicting agendas. ${ }^{153}$ Consequently, they may feel that they have to split their priorities and choose one approach over the other. They may also come in conflict with the movements, although being largely in favour of their political agenda. The articulation of minority and women's rights as separated and even irreconcilable discourses not only influences political and legal practices, but as moral values also establishes a moral dilemma for some women, who feel that they have to choose between being Romani or feminists. Representational intersectionality is a third problematic issue. This concept highlights how minority women often experience limited influence on matters that concern them. The previous sections illustrated how representational intersectionality is an issue for Romani women. ${ }^{154}$ They have traditionally been marginalised both in Romani politics and women's human rights politics with the result that Romani women's issues have received scarce attention. Thus, in order to have an adequate knowledge of minority women's particular concerns it is necessary that the women themselves have the possibility to represent their own interests.

Developing a comprehensive awareness on intersectional discrimination that embraces the different forms of intersectionality present in the lives of many minority women can serve to strengthen the perspective on minority women within the human rights field. In other words, it can enable a stronger focus on minority women within contemporary human rights discourses. This will enhance the relevance of human rights as a legal framework that protects the life and human dignity of minority women, and other subjects who experience discrimination and human rights abuse on multiple grounds.

\subsection{Intersectionality as Part of International Human Rights Approaches}

The previous sections shed light on emerging legal and political approaches within the human rights field towards combining gender and race/ethnicity issues. The CEDAW and CERD Committees have been highlighted as progressive with recent state reviews that take the multiple discrimination of minority women into account, also particularly of Romani women. A recent state review of Hungary by the Independent Expert on Minorities is another example, and here the concept

\footnotetext{
153) Crenshaw, supra note 7, p. 1252.

154) Crenshaw, supra note 7, p. 1282. The author presents a discussion on representational intersectionality as the cause for misleading cultural images of Black women. This discussion is, however, beyond this thesis.
} 
"intersectional" discrimination is expressly used in two paragraphs. ${ }^{155}$ Also, the South organisations in the global women's movement push for further international action against the problem and the Romani women reports and projects at European level highlight the problem of multiple discrimination. However, in order to adequately address the human rights concerns of minority women, and other subjects who experience discrimination and human rights abuse on multiple grounds, it is necessary to have a systematic approach to intersectionality that takes the different structural, political and representational dimensions into consideration. It is not sufficient to use the concept fragmented in a few reports, often without any definition, as this will make intersectionality merely another theoretical concept with little effect for changing practice. ${ }^{156}$

On this basis, effective appropriation of intersectionality into contemporary international human rights practices is one step in the direction of ensuring a comprehensive approach to the human rights of minority women. This would ensure that international practices on race/ethnicity and gender matters also give special and systematic attention to problems of interrelated grounds of discrimination (in the areas of programming, monitoring, interpreting, implementing, etc.). In other words, a mainstreaming attitude could develop around the issue of intersectionality, bearing in mind the methodological implications and difficulties of mainstreaming. ${ }^{157}$ Here, the CERD Committee's General Comment no. 25 can serve as an example. It presents a methodology for analysis of the genderrelated dimensions of racial discrimination. This consists of a four-step inquiry that investigates the nature of the violation, the contexts in which it took place, the consequences and the availability and accessibility of remedies and complaint mechanisms. ${ }^{158}$ This methodology can serve as inspiration for other monitoring bodies to combine gender and racial/ethnicity perspectives in their future work. Another step that can be taken is to include intersectional perspectives in the development of new human rights standards. This would establish a new approach where multiple discrimination and human rights violations are not only confronted through interpretations and combinations of existing bodies of law and policies, but also part of new legal and political developments. This could enable

155) Paragrahs 33 and 75 of Report of the Independent Expert on Minority Issues: Mission to Hungary, 26 June-3 July 2006, UN Doc. A/HRC/4/9/Add.2, 4 January 2007.

156) An example of a fragmented and unexplained use of the concept is the Report of the Independent Expert on Minority Issues: Mission to Hungary, ibid.

157) "Mainstreaming" is much debated in the international community. It is criticised that the concept is used varyingly and inconsistently and also that the UN mainstreaming models have shown little result. M. O'Flaherty and C. O'Brien, 'Reform of the UN Human Rights Treaty Monitoring Bodies: A Critique of the Concept Paper on the High Commissioner's Proposal for a Unified Standing Treaty Body', 7:1 Human Rights Law Review (2007) pp. 141-172, at p. 169. This discussion is, however, beyond the scope of this thesis as it requires an investigation of effective implementation methodologies.

158) General Comment no. 25: Gender-related Dimension of Racial Discrimination, 20/03/2000. 
future jurisprudence to have a broader inclusion of the complex aspects in the violations of minority women's human rights.

The analysis of human rights law illustrated how the traditional separation between gender and race/ethnicity issues makes it difficult to address the full dimensions of this interrelated discrimination and human rights abuse that Romani women experience. The A.S. v. Hungary case but also many other cases before the HRC, CERD Committee and ECtHR exemplify how only some aspects of the case are addressed, and how this sometimes does not do full justice to the case, such as in the Buckley v. UK case, where no violation was found of the Romani woman's right to housing and where minority and in particular the gender aspects where not included and never combined. In order to adequately approach the complexities surrounding minority women, it is necessary that international human rights discourses take the different forms of structural intersectionality minority women can experience further into account. Making it possible to address rights violations cutting across different conventions would not only target the comprehensive structural discrimination that Romani women experience in society. It would also broaden the responsibility of redress to several state institutions involved with gender issues, minority issues, etc. Creating duties within several state institutions has the advantage of creating a stronger basis for solutions. However, there always lies a pitfall of spreading responsibility to such an extent that nothing is implemented if adequate monitoring mechanisms are not established.

Last, defining new approaches that are more inclusive of the subject of minority women paves the ground for further participation of minority women in the interpretation and normative development of human rights projects. Inclusion of local actors in the design of projects that concern them is important to avoid reproducing a representational disempowerment of minority women. Local relevance of human rights is essential for the legitimacy of human rights as universal norms. ${ }^{159}$ This is the argument of the Romani Women's Network (IRWN) that calls for increased international support of community-based models of Romani women's initiatives, inclusion of community-based organisations in policy and programme development, community education and political training in particular of young leaders.

Changing normative discourses towards combining grounds of discrimination is, however, a challenge for a human rights system that is structured around separated categories, best illustrated by the UN treaty body system. Manfred Nowak, Michael O'Flaherty and other recognised scholars and human rights practitioners criticise the functions of the separated institutional system and discuss the

159) K. de Feyter, 'Localising Human Rights', in W. Benedek, K. de Feyter and F. Marella (eds.), Economic Globalization and Human Rights (Cambridge University Press, 2007) pp. 19-41, at pp. 26 and 37. 
possibilities that lie in establishing a unified UN treaty body as a general monitoring mechanism of human rights. ${ }^{160}$ The neglect/exclusion of minority women's human rights issues is only one empirical example of the pitfalls that may arise in a thematically separated human rights system because in reality people do not live "single-issue" lives. However, this article (which summarizes my thesis) did not aim to present a comprehensive reform of the UN system as the solution to the human rights problems of minority women. This is a large and complex contemporary debate. A unified UN treaty body could also risk neglecting minority women's concerns because of an overload of issues, bureaucracy and resource mismanagement. It also risks losing the expertise developed in the different treaty bodies, such as for example CEDAW Committee's comprehensive approach to gender-discrimination. ${ }^{161}$ What this article instead planted is the necessity of integrating intersectionality into contemporary human rights activities, to ensure systematic and adequate attention to the problem, not just in CERD Committee and CEDAW Committee but also in HRC and ECtHR. An inclusion of intersectional considerations in the future elaboration of international and regional human rights instruments and monitoring institutions is also necessary. This requires a more efficient mainstreaming also of minority and gender perspectives in international practices. As the case of Romani women's political participation highlighted, a quantitative increase of women participants does not alone ensure that gender-perspectives are adequately integrated in the work of organisations; additional steps should be taken towards addressing gender-issues. ${ }^{162}$

\section{Conclusion}

This article has addressed the Romani women's issue within a broader framework of the human rights of minority women. The intention was to present new insight into the complexities surrounding these women within contemporary human rights law and politics. It was shown how Romani women, and minority women in general, have significant limitations in finding legal and political support for the human rights violations they experience where gender and ethnicity are interrelated grounds and where discrimination has both internal and external dimensions. While on the one hand they are entitled to two categories of specific rights

160) Concept Paper on the High Commissioner's Proposal for a Unified Standing Treaty Body, HRI/MC/2006/2; M. Nowak, 'The Need for a World Court of Human Rights', 7:1 Human Rights Law Review (2007) pp. 251-259; O’Flaherty and O'Brien, supra note 157, pp. 141-172.

161) O'Flaherty and O'Brien, supra note 157, p. 150.

162) The feminist legal scholar Hilary Charlesworth argues that despite the adoption of a gendermainstreaming vocabulary, little implementation is seen as ensuring gender perspectives in planning, monitoring, follow-up activities, etc. Charlesworth in O'Flaherty and O'Brien, supra note 157 , p. 170 . 
in addition to general human rights, they are on the other hand often excluded from these rights discourses because women and minority issues are traditionally separated categories. Although legal and political approaches to the human rights of women and minorities challenge general human rights law by calling for the special accommodation and protection of disadvantaged groups, they have the pitfall of isolating one identity and set of experiences (gender or minority). Thereby they often neglect intra-group differences such as those carried by minority women.

Consequently, Romani women have more possibilities for addressing aspects of the discrimination they experience where they can draw on different areas of human rights law and politics. The anti-racial/minority rights framework can serve to confront external discrimination against them as members of a minority group, and the women's human rights framework serves to confront gender-based discrimination in society and also internally within their own communities. Thus, in addition to ensuring substantive human rights for women, the women's rights framework also gives weight to an internal feminist project for changing traditional gender-relations within Romani families/communities that may constrain the freedoms of women. Although limited by the lack of provisions that combine gender and minority issues within the law, in some instances anti-racial/minority rights can indirectly work to the benefit of Romani women's advancement also as women. Vice versa, women's human rights may also benefit their advancement as minorities. In particular CERD and CEDAW proved to have these possibilities and are legal avenues that could be explored further for the litigation of minority women's cases. Such new ways of using CERD and CEDAW are highly important to redress the concerns of Romani women. Similar mutual reinforcement can be made of the political framework, where Romani women can use women's human rights fora to find political support for the Romani minority rights project. This way the combination of different areas of human rights law and politics can serve to enhance the political recognition and legal protection of different aspects of Romani women's human rights concerns. This is a strategy through which the Romani women's movement can gain more support and resources for their initiatives since they are so far very isolated in their activity.

It is, however, in this regard that the issue of Romani women, and of minority women in general, presents a challenge to the international human rights framework. When Romani women are forced to split their human rights concerns and prioritise one area of concern over another, it questions the all-inclusiveness of the human rights framework as it does not fully and constructively respond to the particular complexities causing the infringement of the human dignity of these women and other subjects who experience discrimination on interrelated grounds. It was argued that in order to strengthen the validity of human rights in the lives of Romani women, as a framework that ensures their full and equal protection, focus must be strengthened on the issue of intersectionality. The concept of 
intersectionality was re-introduced in a contemporary human rights situation. It is a concept which serves to frame new approaches to minority women within human rights, where the various intersections between race/ethnicity and gender causing their disempowerment are given further consideration in legal and political practices and future developments. Intersectionality must be approached comprehensively (in all its forms) and practically (in the work of the organisations). Importantly it must not be made yet another all-encompassing theory of identity, as this would only reproduce the isolation of Romani women within human rights. To the contrary, the concept serves to include perspectives on multiple grounds of identity into contemporary legal and political human rights discourses in order to give attention to often overlooked areas of minority and women's concerns, where certain categories within these groups face different human rights problems. 